\title{
[1494] Heinrich Bernhard von dem Appelle en de studie van het Fries in de eerste helft van de achttiende eeuw
}

\author{
Redmer Alma
}

Zusammenfassung. Bislang war völlig unbekannt, dass zu denjenigen, die sich während der ersten Hälfte des 18. Jahrhunderts mit dem Studium des Friesischen beschäftigten, auch der ostfriesische Adlige Heinrich Bernhard von dem Appelle (1686-1767) gehörte. Das lässt sich dadurch erklären, dass von dem Appelle nichts darüber veröffentlichte, ganz im Gegensatz zu seinem Landsmann Matthias von Wicht (1694-1778), der aufgrund der von ihm besorgten wichtigen Herausgabe des ostfriesischen Landrechts (1746) zu Ruhm gelangte als Pionier im Bereich der Studie des altfriesischen Rechts. Das politische Schisma Ostfrieslands während des zweiten Viertels des 18. Jahrhunderts hat, seit dem Ausbruch des eben nach von dem Appelle benannten Appelle-Krieges (1725-1727), einen aktiven Austausch zwischen den beiden an ähnlichen Sachverhalten Interessierten verhindert, waren sie doch prominente Anhänger der beiden konkurrierenden Parteien.

Von dem Appelles Hauptverdienst ist zweifelsohne die Entdeckung der ersten Hunsingoer Handschrift (H1) im Jahre 1715. Er stellte die von ihm verfertigte Abschrift dieser Handschrift von Wicht, mit dem er damals noch nicht verfeindet war, zur Verfügung, der in seinem Magnum Opus ausführlich über dieses Manuskript berichtete, jedoch ohne jegliche Erwähnung von von dem Appelles Namen. Obwohl von Wicht die Originalhandschrift niemals zu Gesicht bekommen hat, ist sie dennoch - somit zu Unrecht-als 'Ms. Wicht' bekannt geworden.

Aus von dem Appelles umfangreichem, aber zerstreutem Nachlass sowie aus den bisher ebenfalls noch nicht von der Forschung ausgewerteten handschriftlichen Aufzeichnungen von von Wicht, lässt sich ein ziemlich scharfes Bild der östlich der Ems während der ersten Hälfte des 18. Jahrhunderts aufblühenden friesischen Sprachforschung zeichnen. Hierzu sei angemerkt, dass diese Forschung in Gang gesetzt wurde von in der Isolation operierenden Interessierten, die durch die beschränkte Verfügbarkeit von Quellen und Literatur behindert wurden. Diese Hindernisse sollten erst während der zweiten Hälfte des achtzehnten Jahrhunderts durch die Aufdeckung von weiteren altfriesischen Rechtshandschriften, eine bessere KomUs Wurk 69 (2020), s. 1-37; https://doi.org/10.21827/5e95aae828cd4 
munikation und die Fortschritte im Bereich der Sprachwissenschaft weitgehend beseitigt werden.

Wenn auch von dem Appelles Tätigkeit für die Frisistik als von beschränkter Bedeutung gewürdigt werden muss, so ist er dennoch als einer der Pioniere dieses Zweiges der Germanistik einzustufen, dessen Vorgehensweise als charakteristisch für die wissenschaftliche Praxis seiner Zeit betrachtet werden kann.

\section{Een onderbelicht man $^{1}$}

Een veelzijdig man met een leven dat vele facetten kende, zo kan men Heinrich Bernhard von dem Appelle (1686-1767) zonder overdrijving karakteriseren. Zijn leven was lang, zijn carrière kort maar onstuimig. In 1718 werd hij administrator van de Oost-Friese ridderschap om deze functie na zes jaar weer te verliezen toen de strijd tussen de Oost-Friese standen en de graaf tot uitbarsting kwam, een burgeroorlog die naar hem, als aanvoerder van het militaire verzet tegen de graaf, bekend is komen te staan als Appelle-Krieg (1725-1727). Tot het uitsterven van het gravenhuis en de overgang van Oost-Friesland naar het koninkrijk Pruisen in 1744 verbleef hij vervolgens in ballingschap, o.a. in Groningen en Den Haag. Pas in dat jaar werd hij in het bezit van zijn geconfisqueerde goederen hersteld en kreeg hij zijn functie als administrator terug, om deze al in 1749 weer te verliezen. Uiteindelijk heeft hij in zijn tachtigjarige leven slechts tien jaar lang een bezoldigde functie bekleed.

Maar het is niet alleen zijn politieke leven waarvoor hij de aandacht van het nageslacht verdient. Hij was een veelzijdig amateur-wetenschapper en liet een grote erfenis aan handschriften, archieven en oorkonden na. Veel van zijn activiteiten waren genealogisch en heraldisch van aard en op dat gebied was hij niet alleen een belangrijk en ijverig verzamelaar, zoals meer van zijn tijd- en standsgenoten, maar zijn werken getuigen van een opmerkelijke kritische vaardigheid. Hij schreef honderden oorkonden af, excerpeerde cartularia en handschriften, beschreef grafzerken, glas-in-loodramen en andere gedenkwaardigheden in kerken en huizen en zo zijn er vele thans verloren bronnen die wij enkel dankzij zijn nauwkeurige registraties kennen. In het Ostfriesisches Urkundenbuch zijn honderden middeleeuwse oorkonden opgenomen waarvan de inhoud enkel door zijn prachtig gecalligrafeerde afschriften overgeleverd is. Niet alleen verzamelde hij, maar - en dat onder-

1. De auteur dankt Philippus Breuker, Henk Meijering, Anne Popkema en Oebele Vries voor waardevolle opmerkingen en aanvullingen. 
scheidt hem van veel andere antiquaren uit zijn tijd - hij gebruikte en interpreteerde de bronnen kritisch bij het samenstellen van genealogieën en andere onderzoekjes.

Het wonderbaarlijkste van deze man is echter dat hij, ondanks zijn belang voor vele aspecten van de Oost-Friese geschiedenis, nog niet eens een eigen Wikipedia-pagina heeft en een biografie ontbeert die aan alle facetten van zijn leven aandacht besteedt. ${ }^{2}$ Met name zijn wetenschappelijke en literaire arbeid is nog nauwelijks belicht. Een belangrijke reden hiervoor is natuurlijk dat hij zelf nooit een werk in druk heeft laten verschijnen, ${ }^{3}$ anders dan zijn tijdgenoot Matthias von Wicht (1694-1778), die met zijn uitgave van het Oost-Friese Landrecht in 1746 terechte aandacht en respect van de frisistiek verwierf. Een andere reden ligt hierin dat zijn collectie handschriften na de dood van zijn zoon in 1792 uiteen viel. ${ }^{4}$ Tientallen handschriften heb ik tot dusver kunnen lokaliseren, verspreid over verschillende collecties. Daaronder zijn afschriften van boeken en bronnen van zijn hand, eigen geschriften en door hem verzamelde of verkregen handschriften. Niet altijd is duidelijk welke geschriften hij uit hoofde van zijn functie opstelde en behield, en welke hij uit eigen interesse verzamelde. Dat geldt in het bijzonder voor de juridische en rechtshistorische handschriften.

In dit artikel besteden wij aandacht aan het belang van Von dem Appelle voor de studie van het (Oud)Fries en het Oudfriese recht. Dat belang is beperkt en indirect. Bij mijn weten is binnen de frisistiek zijn naam nog niet

2. De op zich mooie biografie van De Vries (J.F. de Vries, 'Heinrich Bernhard von dem Appelle', Jahrbuch der Gesellschaft für bildende Kunst und vaterländische Alterthümer zu Emden VII, Heft 2 (1888) 73-103) besteedt met name aandacht aan zijn politieke en persoonlijke leven en wel beperkt tot de periode tot 1744 . Korte biografische schetsen geven Tileman Dothias Wiarda, Ostfriesische Geschichte VIII. von 1734 bis 1758 (Aurich 1798) 479; M. Herborg, Das gelehrte Ostfriesland im 18. und 19. Jahrhundert, Handschrift, Johannes-a-Lascobibliothek Emden (hierna: JaL-B), Ms. Kunst, nr. 325 (oud 685), s.v. Appelle.

3. Ruim een eeuw na zijn dood verscheen zijn in 1717 geschreven 'Kurtze und eilfertige Nachricht wegen des Uhralten Geschlechts derer von Beninga von Anfang biß itzt zu' (Albert Pannenborg, 'Heinrich Bernhard von Appell über das Geschlecht der Beninga', Ostfriesisches Monatsblatt für provinzielle Interessen VI (1878) 433-442, ald. 435-442, vermoedelijk naar het handschrift in Dep. 40a, inv.nr. 11, momenteel onvindbaar). Verder zijn vele door hem verzamelde genealogische schema's, oorkonden en grafzerken door anderen gebruikt en uitgegeven, maar eigen pennenvruchten zijn verder bij mijn weten nooit gepubliceerd. Tenzij anders vermeld berusten de hierna aangehaald archieven in het Niedersächsisches Landesarchiv - Abteilung Aurich.

4. Zie uitgebreider: Redmer Alma, 'Die Grimersumer Kiste', Emder Jahrbuch 100 (2020) 353-367. 
eerder gevallen. ${ }^{5}$ In het algemeen is in de (Nederlandse) literatuur over de geschiedenis van de frisistiek en het Oudfriese recht zelden of nooit gebruik gemaakt van handschriftelijke bronnen of archieven in Oost-Friesland, maar heeft men zich daarvoor enkel gebaseerd op informatie uit gedrukte werken. De paedwizers ten oosten van de Eems in de eerste helft van de achttiende eeuw en hun onderlinge samenhang zijn daardoor structureel onderbelicht gebleven $^{6}$ en in die lacune willen wij hier ten dele voorzien. $\mathrm{Na}$ een overzicht van de beginsituatie rond 1700 zullen we min of meer chronologisch de hoofdrolspelers en hun onderlinge samenhang volgen, met vanzelfsprekend met name aandacht voor de activiteiten van Von dem Appelle.

\section{Friese bronnen in het begin van de achttiende eeuw}

De wetenschappelijke studie naar het Fries en het Oudfriese recht werd rond 1700 sterk gehinderd door het vrijwel geheel ontbreken van bronnen. De belangrijkste Oudfriese bronnen die wel beschikbaar waren, werden gevormd door de teksten die in 1658 door Schotanus waren uitgegeven: de incunabel met het Westerlauwers-Friese landrecht, beter bekend als Druk, de Willekeuren van de Opstalsboom, het Tractaat van de Zeven Zeelanden en de Willekeuren van Wildinge. ${ }^{7}$ Verder was de uitgave van de Lex Frisionum van Siccama uit 1617 bekend, waarin Oudfriese fragmenten opgenomen zijn. ${ }^{8}$ Een andere belangrijke bron voor de kennis van het Fries waren de door Gabbema opgenomen teksten in de Friesche Rymlerye van Gysbert Japicx (1681-1684).

Het 'Fivelgoër' handschrift (F) was al vroeg voor onderzoekers beschikbaar, in elk geval toen het in de zeventiende eeuw in eigendom was van de Groninger raadsheer Warnerus Emmen (1626-1679). Simon Abbes Gabbema (1628-1688) en Franciscus Junius (1589-1677) hebben het toen kunnen

5. Recentelijk A.P. de Jong, Knooppunt Halbertsma. Joast Hiddes Halbertsma (17891869) en andere Europese geleerden over het Fries en andere talen, over wetenschap en over de samenleving (Hilversum 2009).

6. H.T.J. Miedema, Paedwizers fan de Fryske filology (Leeuwarden 1961) 20.

7. Christianus Schotanus, De geschiedenissen kerckelyck ende wereldtlyck van Friesland Oost ende West; beginnende van d'eerste geheuchenis ende vol-trocken tot op het iaar na Christi Geboorte 1583 (Franeker 1658), Tablinum, 18-20, 75-76; dez., Beschryvinge van de heerlyckheydt van Frieslandt tusschen 't Flie end de Lauwers (Franeker 1664).

8. Sibrandus Siccama, Lex Frisionum sive antiquae Frisiorum leges, a reliquis veterum Germanorum legibus separatim aeditae et notis illustratae (Franeker 1617). Vgl. H. Nijdam en A. Versloot, 'Kodeks Siccama: spoaren fan in ferdwûn Aldwestfrysk rjochtshânskrift', Us Wurk 61 (2012) 1-56. 
raadplegen. ${ }^{9}$ Een eeuw later was het in bezit van D.F.J. van Halsema (17361784), maar in de tussenliggende periode was de verblijfplaats aan geïnteresseerde onderzoekers niet bekend. Het Tweede Hunsingoër Handschrift (H2) was eerder al gebruikt door Ubbo Emmius (1547-1625) voor zijn Historia Frisiae. Het afschrift van de Oudfriese tekst van zijn hand is door D.F.J. van Halsema in 1778 uitgegeven, maar in de tussenliggende 150 jaar was het voor onderzoekers onvindbaar. ${ }^{10}$ Het handschrift zelf kwam pas weer tevoorschijn in 1783. Evenmin wist men dat Johan Rengers van ten Post (1542-1626) van hetzelfde handschrift een afschrift had vervaardigd.

De interesse voor het Fries was in de zeventiende eeuw in Oost-Friesland grotendeels beperkt tot twee personen, Imel Agena (ca. 1575-1640/1641) en Johannes Cadovius Müller (1650-1725). Imel Agena schreef en publiceerde in 1632 een Fries bruiloftsgedicht ter gelegenheid van het huwelijk van een achterneef. ${ }^{11}$ Van hem is daarnaast nog enige activiteit op het terrein van het Oudfriese recht bekend. Hij schreef uit een verloren gegaan middeleeuws rechtshandschrift de Zes Overkeuren en de Emsiger Domen over. Deze Overkeuren zijn door Von Wicht in 1746 gepubliceerd en zo voor het nageslacht bewaard gebleven. Het afschrift van de Emsiger Domen, door Agena in de marge van een handschrift met het Oost-Friese landrecht genoteerd, is bij mijn weten nog niet teruggevonden. ${ }^{12}$ Müller liet een belangrijk (Oost-)Fries woordenboek in handschrift na, het Memoriale linguae Frisicae, waarin hij tevens een Friestalig gedicht opnam. ${ }^{13}$ Zijn

9. B. Sjölin, Die 'Fivelgoer' Handschrift (Den Haag 1970) 5-6. Warnerus Emmen was geen familie van Ubbo Emmius, zoals dikwijls ten onrechte beweerd wordt.

10. D.F.J. van Halsema, Het aloude Ommelander wetboek van Hunsingo, in de oude oorspronglijke Friesche landtale omtrent 't midden der dertiende eeuw vervaardigd, uit een egt afschrivt naar 't pergamenten uitgegeven (Groningen 1778).

11. F. Holthausen, 'Ostfriesische Studien', '4. Das Hochzeitsgedicht des Imel Agena von 1632', in: Beiträge zur Geschichte der deutschen Sprache und Literatur L (1927) 6071; Marron Fort, 'Das Hochzeitsgedicht des Rentmeisters Imel Agena van Upgant aus dem Jahre 1632', Jahrbuch für das Oldenburger Münsterland XLIX (2000) 204-211.

12. C. Borchling, Die niederdeutschen Rechtsquellen Ostfrieslands I (Aurich 1908), noch W. Schulz, 'Die Studien zur Genese und Überlieferung des ostfriesischen Landrechts', Jahrbuch der Gesellschaft für bildende Kunst und Vaterländische Altertümer zu Emden 72 (1992) 81-169, of andere auteurs op het terrein van het Emsingoër recht maken melding van een handschrift met deze marginale aantekeningen. Elders hoop ik hier nader op in te gaan.

13. Johann Cadovius-Müller, Memoriale linguae Frisicae mit Zugrundelegung der in Aurich befindlichen Originalhandschrift, L. Kükelhan ed. (Leer 1875); dez., Memoriale linguae Frisicae: nach der Jeverschen Originalhandschrift, Erich König ed. $\left(1911,2017^{2}\right)$. 
werk is tekenend voor de rond 1700 ontluikende belangstelling van geleerden in de gesproken taal als historisch-taalkundige bron, die hieronder zal blijken. Daarmee hebben we de actieve beoefening van het Fries in de zeventiende eeuw ten oosten van de Eems geheel behandeld.

Het werk van Müller sluit aan op een derde aspect - naast rechtsbronnen en gesproken taal - dat in de vroeg-achttiende-eeuwse frisistiek aandacht kreeg: de lexicografie. Hier moest men het voor wat betreft het Oudfries doen zonder voorbeelden. Johan Rengers van ten Post stelde een woordenlijst samen van 94 Oudfriese woorden en uitdrukkingen. ${ }^{14}$ In de zeventiende eeuw werden lexicografische pogingen ondernomen door Franciscus Junius (1591-1677), Jan van Vliet (1620-1666) en Simon Abbes Gabbema). ${ }^{15}$ Pas in 1778 , toen D.F.J. van Halsema aan zijn uitgave van $\mathrm{H} 1$ en $\mathrm{H} 2$ een glossarium toevoegde, verscheen een algemeen toegankelijke Oudfriese woordenlijst en in 1786 was het aan de Oost-Fries Tileman Dothias Wiarda (1746-1826) om het eerste Oudfriese woordenboek te laten drukken. ${ }^{16}$ Geen van de eerdere woordenlijsten of aanzetten tot woordenboeken waren rond 1700 aan geïnteresseerde onderzoekers bekend.

Ziedaar de stand van zaken met betrekking tot de kennis van het (Oud)fries en de middeleeuwse rechtsbronnen bij het ingaan van de achttiende eeuw. Als we het corpus van de tien thans bekende Oosterlauwerse Oudfriese handschriften overzien, ${ }^{17}$ dan was geen ervan bij de aanvang van de achttiende eeuw voor onderzoekers beschikbaar, terwijl zij een eeuw later alle tien waren herontdekt.

Toch was in materieel opzicht het Oudfriese recht in Oost-Friesland dichterbij dan elders. Omstreeks 1520 heeft graaf Edzard het vigerende (vooral Emsingoër) recht laten samenbrengen en bewerken tot een algemeen geldend Oost-Fries landrecht. Na bijna twee eeuwen was deze verzameling middeleeuws recht, vergeleken met dat van de andere Friese landen, een archaïsch rechtsboek geworden, dat bovendien enkel in handschrift beschikbaar was. Dit was de reden dat Matthias von Wicht opdracht kreeg

14. P. Gerbenzon, 'In Aldfrysk glossarium fan Johan Rengers fan Ten Post', Us Wurk X (1961) 39-43.

15. Ph.H. Breuker, 'On the course of Franciscus Junius Germanic studies, with special reference to Frisian', in: R.H. Bremmer, G. van der Meer en O. Vries (red.), Aspects of Old Frisian philology (1990) 42-68; R.H. Bremmer, 'De leksikografy fan it Aldfrysk', in: A. Dykstra en R.H. Bremmer, In skiednis fan 'e Fryske taalkunde (Leeuwarden 1999) 75-76; O. Vries, 'In ûnbekend Aldfrysk glossarium fan S.A. Gabbema', Us Wurk 52 (2003) 120-129.

16. Bremmer, 'De leksikografy', 76-77.

17. Van oost naar west: R1-2, B1-2, E1-3, F en H1-2. 
een editie voor te bereiden. Omdat dit landrecht voornamelijk een compilatie van Oudfriese rechtsteksten was, was vergelijking met de middeleeuwse bronnen voor de interpretatie en de rechtshistorische genese van belang. Von Wicht nam die taak voortvarend ter hand. Vijftien jaar later leidde dat in 1746 tot zijn enige serieuze publicatie op het gebied van het Oudfriese recht, maar die telde dan ook 1.170 pagina's, exclusief de registers, en daarmee vestigde hij blijvend zijn reputatie. ${ }^{18}$ Ook zijn succesvolle pogingen om rechtshandschriften tevoorschijn te brengen, zijn gewaardeerd, wat hieruit blijkt dat maar liefst drie handschriften (B1, E3 en H1) lange tijd bekend hebben gestaan als 'Ms. Wicht'.

\section{Het Eerste Rüstringer handschrift}

Het eerste van de tien Oosterlauwerse Oudfriese rechtshandschriften dat ontdekt werd, was het eerste Rüstringer handschrift (R1). Het werd in 1703 gevonden in het Oldenburger archief door Johann Christian Schroetern (1672-1719), predikant te Strückhausen en Ovelgönne (in de omgeving van Bremen). ${ }^{19}$ Schroetern deelde zijn vondst met en zond gedeeltelijke afschriften ervan aan geleerde germanisten als Johannes Moller (1661-1725), Johann Hinrich Eggeling (1639-1713), Gottfried Wilhelm Leibniz (16491716), Johann Georg von Eckhart (1664-1730) en Diederik von Stade (1637-1718), die zich er dankbaar op stortten. ${ }^{20}$ Von Stade meldt al op 25 november 1709 dat hij 'mit dem Glossario hoffe bald fertig zu werden'.2

Uit de correspondentie tussen deze geleerden blijkt hoe men probeerde de taal van dit handschrift een plaats te geven temidden van de andere Germaanse talen. Schroetern denkt dat het Rüstringer handschrift geschreven is in 'die alte Friesische Sprache, so mit der alten Fränkischen einige Gemeinschafft hat ${ }^{22}$ en Mollerus stemt daarmee in. ${ }^{23}$ Zijn aarzelende constatering is niet verwonderlijk, want er waren nauwelijks bronnen waaraan men kon refereren. De werken van Gysbert Japicx waren uiterst lastig te

18. M. von Wicht, Das ostfriesische Land-Recht, nebst dem Deich- und Syhlrechte (Aurich 1746).

19. Niet te verwarren met de veel bekendere rechtsgeleerde Johann Christian Schröter (1659-1731).

20. Zie ook: W.J. Buma, De Eerste Riustringer Codex ('s-Gravenhage 1961) 4.

21. Memoria Stadeniana, sive de vita, scriptis ac meritis Diederici a Stade commentarius, I.H. a Seelen ed. (Hamburg 1725) 289.

22. Memoria Stadeniana, 286.

23. Memoria Stadeniana, 298. 
vinden, zeker in de omgeving van Bremen. ${ }^{24}$ Ook de nog bestaande spreektaal was vanuit de studeerkamers nog geen voor de hand liggende bron, zo blijkt uit een van de observationes van Diederik von Stade: 'Dass die Friesische Sprache im Lande Wursten bey den Friesen noch im Gebrauch, solches habe aus der Erfahrung, und hat mir bey der Visitation ein Friese selbst gesagt, dass er in seinem Hause mit Frau und Kindern immer Friesisch rede. So berichten auch Pastores zu Imsum, besage Protocolli Visitationis de a. 1686 d. 24 Jul., dass bey den Friesen bey einer Leiche eine Friesische Abdanckung geschehe. Miscell. p. 277. ${ }^{25}$ Dat het Fries uit het Angelsaksisch stamt, kan volgens hem verklaard worden uit de vroegere intensieve handelscontacten, zoals blijkt uit de vele kerken in Wursten die van 'Dopfsteen' zijn gebouwd, die daar te lande niet gevonden wordt, maar wel in overvloed in Engeland aanwezig is. ${ }^{26}$

De worsteling van de germanisten en de wijze waarop men zich op kenbronnen beriep, komt op ons komisch over - er waren zelfs geleerden die de gotische bijbelvertaling van Ulfilas voor het oudste Fries hielden. ${ }^{27}$ Het schetst hoe men nog zocht naar classificatie en onderlinge verhoudingen van de verschillende talen en dialecten. Het geleerde discours van die dagen kon nog niet steunen op wat voor ons vanzelfsprekend 'Fries' is. Pas enige jaren later kreeg men beperkt beschikking over echte Friestalige teksten in Westerlauwerse publicaties, zoals Siccama en Gysbert Japicx.

Eckhart kende in 1711 de uitgave van de (Latijnse) Lex Frisionum door Sibrandus Siccama uit 1617 en de daarin opgenomen passages uit een Oudfries rechtshandschrift. ${ }^{28}$ Hij voegde er de wens aan toe dat de recentere wetten die in de 'patria lingua' waren opgesteld, uitgegeven zouden worden.

24. 'Rarissimus est hic liber tum alibi, tum in ipsa Frisia'. Gerhard Outhof schrijft aan Christianus Funck, predikant te Aurich: 'Tot antwoordt op des Hr. Vonks begeerte diendt, dat ik van dat werk van Gisberts Iapix Friesche Rymeleryen wel gehoordt hebbe; maar ik hebbe het niet, en kan der ook geen nader berigt van doen. Unde summa libri raritas satis apparet. (Memoria Stadeniana, 97-99).

25. Memoria Stadeniana, 367.

26. Memoria Stadeniana, 380-381: 'In specie Frisicam linguam hac de causa ex A.S. natam statuo, ob convenientiam vocum. Et Frisios quidem et A. Saxones olim maius habuisse commercium, ac nunc, inde liquere puto, quod in nostra Frisiorum Wursatia in Wremen tot Ecclesia ex lapide, quem Dopfsteen vocant, exaedificata sit, qui lapis apud nos non invenitur, in Anglia vero copia istius maxima reperiatur, Collect. Misc. in 8. p. 41 sq.' Vgl. het commentaar van Von Wicht op deze passage: Dep. 1 Msc., inv.nr. Q 153, fol. 256v.

27. Memoria Stadeniana, 56.

28. J.G. Eccardus, Historia studii etymologici linguae Germanicae hactenus impensi (Hannover 1711), 68. 
Hiervan waren immers zeer oude exemplaren in bibliotheken van geleerde mannen bewaard gebleven. ${ }^{29}$ Eén voorbeeld uit een dertiende-eeuws handschrift heeft hij gezien, R1, waarvan hij het door Schroetern verstrekte fragment opneemt. ${ }^{30}$ Uit de andere teksten die hij in het vervolg noemt, blijkt dat hij niet specifiek op Oudfriese handschriften doelt die daadwerkelijk in bibliotheken van geleerde mannen beschikbaar zijn. ${ }^{31}$ Meer Oudfriese teksten dan de door Siccama uitgegeven fragmenten en het nieuw gevonden R1 kende hij niet.

Interessant is overigens dat Eckhart de hem onbekende taal als 'patria lingua' aanduidt, terwijl Eggeling zelfs spreekt over 'unsere liebe alte Mutter-Sprache'. ${ }^{32}$ Hun wetenschappelijke interesse wordt blijkbaar versterkt doordat zij de taal verbinden met hun historische identiteit.

In 1725 geeft Johann Henrich von Seelen (1687-1762) postuum de geschriften van Von Stade uit. Hieruit blijkt dat de laatste de werken van Gysbert Japicx gekend heeft ${ }^{33}$ en er zelfs een glossarium op vervaardigd heeft. ${ }^{34}$ De door Schotanus uitgegeven Oudfriese teksten waren al deze Noord-Duitse taalkundigen onbekend, evenals de lokale initiatieven op het gebied van het Wurstfriesisch door Luder Westing (1688) en D.A. Witte (ca. 1720). ${ }^{35}$ Wel kende Leibniz het Memoriale linguae Frisicae antiquae van Johannes Cadovius Müller. ${ }^{36}$

We zijn wat nader ingegaan op deze geleerden om te laten zien hoe zij opereerden op een eiland, binnen hun germanistische discipline, sterk gehinderd door een beperkt overzicht van referentieliteratuur uit de Nederlanden. Hun overlijdensjaren verklaren waarom hun activiteiten enkel in hun taalkundige publicaties werden vastgelegd, maar verder geen direct gevolg

29. 'Et extant hinc inde in bibliothecis virorum doctorum exemplaria vetusta'. Eccardus, Historia, 69.

30. Eccardus, Historia, 69-70.

31. 'Deinde dialectos singularum provinciarum Germanicarum, nec non Belgicam, Frisicam, \& magnae Scandinaviae, Anglo-Saxonicam item veterem \& Gothiam in auxilium voco.' Eccardus, Historia, 329.

32. Memoria Stadeniana, 281.

33. Memoria Stadeniana, 56, 74.

34. 'Voces quaedam Frisicae ex Gisberto Iapix'. Memoria Stadeniana, 144-145.

35. R.H. Bremmer, 'The Study of Frisian to the End of the $19^{\text {th }}$ Century', in: H.H. Munske (red.), Handbuch des Friesischen (Tübingen 2001) 1-11, 3; T.L. Markey, Frisian (Den Haag, Parijs en New York 1981) 253; [Johann Hinrich Pratje], Altes und neues aus den Herzogthümern Bremen und Verden IV (Stade 1771) 382.

36. N.a.v. het woord hevdling: 'teste Mullero MS. Fris. Indice'. G.G. Leibnitzius, Collectanea etymologica illustrationi linguarum, veteris Celticae, Germanicae, Gallicae, aliarumque inservientia (Hannover 1717) 258. 
kenden. We mogen Von Seelen dankbaar zijn dat hij in 1725 in de Memoria Stadeniana de correspondentie in druk heeft laten verschijnen, waardoor het spoor door latere onderzoekers met succes kon worden vervolgd.

De inhoud van het Eerste Rüstringer handschrift bleef voorlopig enkel door de gepubliceerde fragmenten bekend. Na het overlijden van Schroetern in 1719 kwam zijn afschrift in bezit van Theodor Hase (Hasaeus) (16821732) ${ }^{37}$ Deze had goede contacten met Oost-Friese onderzoekers, zoals E.F. Harkenroth (1670-1732), ${ }^{38}$ maar ik heb geen aanwijzingen gevonden dat R1 onderwerp van hun correspondentie geweest is. Het zou nog enige decennia duren voordat het handschrift voor meer onderzoekers beschikbaar was.

\section{Heinrich Bernhard von dem Appelle en het Eerste Hunsingoër Hand- schrift}

Het tweede van de Oosterlauwerse rechtshandschriften dat werd herontdekt, was het Eerste Hunsingoër Handschrift. De eer van de ontdekking komt aan Von dem Appelle toe. Hij beschrijft zelf hoe hij in de zomer van $1716^{39}$ in de Ommelanden bij zijn verre achterneef Carel Ferdinand van In- en Kniphuisen op Nienoord verbleef en daar een vierhonderd jaar oud perkamenten, in gotisch boekschrift geschreven Fries rechtshandschrift, een codex jurium provinciae Frisiae, afschreef.

Cum Anno 1716 aestivo tempore in agro Groningano apud Fredowoldios versarem ibique cognatum Carolum Ferdinandum Comitem a Cnyphusen visitarem, in bibliotheca ejus inveni Codicem perantiquum Juris Provincialis Frisici, ante quadringentos annos in membranis literis uti vocant Monachalibus exaratum, ex illo antiquitatum tum non aeque ut nunc curiosus, neque in hoc studii genere versatus, sequentia excerpsi. ${ }^{40}$

Hij schrijft dus dat hij toen een extract had gemaakt, maar dat hij nog niet

37. Memoria Stadeniana, 180.

38. Dep. 4 IX, inv.nr. 24. 'Sammlung einiger Schriften des Predigers Harckenroth unter der Hand des Herrn vom Appelle mit Anmerkungen von dem Professor Haase in Bremen', o.a. 1. Ad Hasaeum de Martino Fabri et Familia Hadriani VI. Papae; 3. Excerpta ex litteris Eilhardi Folkhardi Harckenrohtii ad Theodorum Hasaeum ad historiam ecclesiasticam Frisiae Orientalis XVI. saeculi; 5. E.F. Harckenroht ad Th. Hasaeum ad historiam sacram et literariam saeculi XVI.'

39. Elders dateert hij een bezoek, waarbij hij schilderijen beschreef en genealogische en heraldische gegevens noteerde, op 1715. Dep. 4 IX, inv.nr. 13, inv.nr. 157, fol. 82r: 'Wie ich im Jahr, ni fallor, 1715 mich einige Zeitt zu Nienoort bey dem letzten Grafe v. Cnyphusen aufhielte, ...' Dep. 4 IX, inv.nr. 9a, fol. 116r, geeft: 'Im Jahr 17...'.

40. Dep. 1 Msc., inv.nr. 60, pag. 32 , fol. $17 \mathrm{v}$. 
'zoals nu' nieuwsgierig was naar dergelijke oudheden noch in dat soort studie bedreven was. Op Nienoord noteerde Von dem Appelle vooral genealogische en heraldische zaken. Het extract van het Oudfriese handschrift maakte hij slechts terloops. Enige jaren later was zijn interesse wel gewekt en voegde hij het extract samen met afschriften uit Schotanus en Siccama, waarmee hij een overzicht had van het meeste wat er aan Oudfries op dat moment voor de geleerde wereld beschikbaar was. Hij was vermoedelijk nog onkundig van de correspondentie die de hiervoor genoemde geleerden gevoerd hadden over R1.

Om een beeld van de wetenschappelijke belangstelling van Von dem Appelle te krijgen geven we een overzicht van de handschriften die Von dem Appelle verzamelde, afschreef, excerpeerde en samenstelde. We kunnen daarbij grofweg de volgende categorieën onderwerpen onderscheiden:

- Genealogische en heraldische werken en bronnen. Deze handschriften vormen het leeuwendeel van zijn verzameling.

- Cartularia en oorkonden betreffende Oost-Friesland. Hieronder is de tweedelige Farrago diplomatum Ostfrisicarum, ${ }^{41}$ een uiterst belangrijke bron voor oorkonden die grotendeels in origineel verloren zijn gegaan.

- Grafzerken, monumenten, glas-in-loodramen, wapenkwartierstaten, opschriften, voornamelijk in Oost-Friesland, maar ook in Groningen ${ }^{42}$ en elders.

- Juridische en politieke bronnen, o.a. met betrekking tot de verhouding van de graven tot de Oost-Friese standen.

- Stukken van en over de gebroeders Harkenroth, o.a. over het proces tussen de graaf en Jacobus Isebrandus Harkenroth, en correspondentie met deze laatste.

- Samenvattingen en afschriften van historische werken.

- Stukken betreffende zijn eigen rechtsstrijd tot herstel in zijn goederen.

- Reisverslagen, door Nedersaksen, naar Münster en Paderborn en naar Potsdam, met uitgebreide beschrijving van Sanssouci.

- Bronnen met betrekking tot de plaats en kerk te Groß Midlum.

- Zegels en munten uit Oost-Friesland

- Diversen: 'Zufällige Gedanken von allerhand Sachen', over het noorderlicht, over grote stukken geschut, Arminius, buskruit, foreestrecht, vrije

41. Aldus de titel die Von dem Appelle aan de verzameling gaf. Ten rechte zou het 'ostfrisicorum' moeten luiden.

42. R. Alma, 'Gebrandschilderd glas aan de Grote Markt', Hervonden stad 4 (1999) $97-$ 102. 
rijkssteden, vrouwenheerschappij, hogescholen, de familie van Hugo de Groot, bijzondere machines, reusachtige dieren en bomen, enz. enz. ${ }^{43}$

Dat Von dem Appelle een brede belangstelling had, is geen gewaagde conclusie als wij zijn werken overzien en nog meer als wij de catalogus van zijn bibliotheek bekijken. ${ }^{44}$ Naast de bovenstaande onderwerpen is er nog een aantal handschriften en teksten die kunnen dienen om zijn werkzaamheden met betrekking tot het Fries en het Oudfriese recht beter te duiden. Dat hij geïnteresseerd was in historische taalkunde, blijkt uit een aantal handschriften. In het bijzonder de geschiedenis, duiding en etymologie van toponiemen, zowel die uit historische bronnen als nog bestaande, hadden zijn bijzondere belangstelling:

- 'Collectanea geographiae Frisiae Orientalis'. ${ }^{45}$

Verzameling vermeldingen van en aantekeningen over eilanden, landen, ambten en plaatsen in Friesland van Vlie tot Wezer, uit gedrukte werken en oorkondelijke bronnen.

- 'Collectaneen ad geographiam Medii Aevi'. ${ }^{46}$

Verzameling vermeldingen van vroeg- en hoog-middeleeuwse toponiemen in verschillende gedrukte werken, zowel in de Nederlanden als (voornamelijk Noord-)Duitsland. ${ }^{47}$

- 'Collectanea etimologiae linguae Germanicae'. ${ }^{48}$

Op de inhoud van dit handschrift gaan we hieronder in.

Puur taalkundig was een middeleeuwse Latijnse grammatica, een handschrift uit het klooster Ebstorf, hem van zijn tante aangeërfd, ${ }^{49}$ maar daarmee lijkt hij zelf niets gedaan te hebben.

In de moderne talen was hij zeer goed thuis. Hij beheerste tot op zeker niveau Hoogduits, Nederduits, Nederlands, Engels, Frans, Latijn, Italiaans

43. Dep. 28 b, inv.nrs. 334 en 335.

44. Dep. 4 IX, inv.nr. 63.

45. Dep. 1 Msc, inv.nr. 61

46. JaL-B, Ms. Kunst, nr. 18 (oud 29).

47. Met betrekking tot Friesland betreft dit o.a. Cornelius Kempius, De origine, situ, qualitate et quantitate Frisiae (Keulen 1588), Suffridus Petri, Historia veterum episcoporum Ultraiectinae sedis, \& comitum Hollandiae (Franeker 1612), Ubbo Emmius, Rerum Frisicarum historia (Leiden 1616), Menso Alting, Descriptio secundum antiquos Agri Batavi \& Frisii una cum conterminis. Sive notitia Germaniae Inferioris (Amsterdam 1697), J.F. Schannat, Corpus Traditionum Fuldensium (Leipzig 1724), J.F. Falck, Codex traditionum Corbeiensium (Leipzig 1752).

48. Dep. 4 IX, inv.nr. 12.

49. JaL-B, Ms. Kunst, nr. 539 (oud 76). 'Grammatica Latina seculo decimoquarto in usum oenobii monialium Saxon. Infer. conscriptum, junctis precibus Latino Germanicis ut videtur exercitii gratiam Latinae a moniali quadam scriptae'. 
en, naar we zullen zien, Oudfries en Fries. ${ }^{50}$ Het handschrift 'Zeitt Vertreib müssiger Stunden' bevat vertalingen van Engelse, Franse, Latijnse en Italiaanse gedichten, alsmede gedichten van zijn eigen hand. ${ }^{51}$

Richten wij ons op de handschriften die concreet van belang zijn voor zijn interesse in het (Oud-)Fries, taalkundig en rechtshistorisch, dan treffen we aan:

- 'Linguae antiquae Frisiacae monumenta et glossarium'. 52

- 'Iuris Provincialis Frisiae Orientalis collatio ex diversis manuscriptis'. 53

- Landrecht van graaf Edzard. ${ }^{54}$

- 'Dat olde Landrecht der Vryen Fresen, ante tempora Comitum', een Nederduitse vertaling van de Zeventien Keuren en de Vierentwintig Landrechten, van een andere hand, maar afkomstig uit de bibliotheek van Von dem Appelle. ${ }^{55}$

Van zijn collectie handschriften op het gebied van de literatuur noem ik, als voor Friesland van belang, enkel een album amicorum van Take van Aylva uit 1575 en een autograaf van Anna Maria van Schurman (16071678), 'Eerste beginselen der christelijcke religio'. ${ }^{56}$ Dit laatste handschrift is vermoedelijk afkomstig van Adelgunt van Diepholt (1622-1684), de eerste vrouw van Von dem Appelles vader, een van de leden van het Fries-

50. Zie ook: T.D. Wiarda, Ostfriesische Geschichte, VIII. von 1734 bis 1758 (Aurich 1798) 480.

51. JaL-B, Ms. Kunst, nr. 47 (oud 74).

52. Dep. 1 Msc, inv.nr. 60.

53. Dep. 1 Msc, inv.nr. 62.

54. Dit handschrift is na de dood van Von dem Appelles schoondochter ingevolge haar testament overgedragen aan de Ostfriesische Landschaft (Dep 28b, inv.nr. 336, fol. 399 en Dep. 4 II c, inv.nr. 9, fol. 386r; zie Alma, 'Grimersumer Kiste', 364-365), maar ik heb het nog niet teruggevonden. Het betrof een afschrift van het exemplaar van het Hofgericht, zoals we hieronder zullen zien.

55. Dep. 1 Msc., inv.nr. 58, fol. 3r-73r. Inc.: Dit Boeck tönet und wijset uns die soventhein Willekür, und die 24 Landtrechten, de Koninck Carel hefft gegeven allen Freesen... Expl.: Die Moder mach nehmen van eren Kinderen des Jahrs vijff schill. vor Luider Lohn, wanner sie einen anderen man hefft genomen, und de Kinder dan mit sick heft all, tho dat sie vii Jar alt sijn, und se eres Vaders Gudt nicht en besittet. Finis.

56. Dep. 4 IX, inv.nr. 63, pag. 191: 'Take v. Ailva, Hand oder Stamm- und GedächtnisBuch mit vielen heroldmäßig gemahleten Wapens, Devisen und Nahmen, 1575', resp. 'An. Mar. Schurmann, Beginselen der christelycken religie (ofte catechismus in vraeg ende antwoord van A.M. Schurmann eygen hand)'. 
Groninger netwerk van dichteressen dat met Anna Maria van Schurman in contact stond.$^{57}$ Dit handschrift is bewaard gebleven. ${ }^{58}$

Het belangrijkste handschrift is echter helaas onvindbaar: een door hemzelf samengesteld glossarium van de Oost-Friese volkstaal. Hierop komen we hieronder terug.

\section{Linguae antiquae Frisiacae monumenta et glossarium}

Het handschrift waarin Von dem Appelle zijn afschrift van H1 opnam ${ }^{59}$, heeft de volgende inhoud.

S. 1-6, Fol. 2r-4v Statuta Upstallesbomica

Willekeuren van de Opstalsboom, 1323, met Duitse vertaling

Naar Schotanus, Tablinum, 18-19.

S. 7-9, Fol. 5r-6r Annotatio de septem Selandis tempore statutae legis precedentis sub Frisia comprehensis

Tractaat van de Zeven Zeelanden, met Duitse vertaling Naar Schotanus, Tablinum, 19-20.

S. 10-13, Fol. 6v-8r Willekeuren van Wildinge, 1379, met gedeeltelijke Duitse vertaling

Naar Schotanus, Tablinum, 75-76.

S. 14-26, Fol. 8v-14v Excerpta ex Sibr. Siccama notis ad antiquas Frisiorum Leges, editis Franequ. 1617 in 4to

Aantekeningen naar Sibrandus Siccama, Lex Frisionum sive antiquae Frisiorum leges, a reliquis veterum Germanorum legibus separatim aeditae et notis illustratae (Franeker 1617).

S. 27-32, Fol. 15r-17v Samenvatting van Siccama, Lex Frisionum, 1-62.

S. 32-39, Fol. 17v-21r Excerpta codicis Jurium Provinc. Frisiae

Extract uit H1, met fragment-glossarium op de Hunsingoër Keuren van 1252

S. 40, Fol. 21v Overzicht van Friestalige stukken in Schotanus

57. Zie: Ph. Breuker, 'Vrouwelijke kunstenaars en hun kringen in het midden van de zeventiende eeuw', in: Margareta de Heer (circa 1600-circa 1665) (Leeuwarden 2002) 41-56, ald. 50; R. Alma, 'Occa Johanna Ripperda. Mutige Entscheidungen einer jungen Witwe', in: K.-D. Voß (red.), Freie Friesentöchter - Tradition und gelebte Wirklichkeit (Oldenburg 2019) 149-156; Alma, 'Grimersumer Kiste', 358-359.

58. JaL-B, Ms. Kunst, nr. 541 (oud 95).

59. Dep. 1 Msc, inv.nr. 60. 


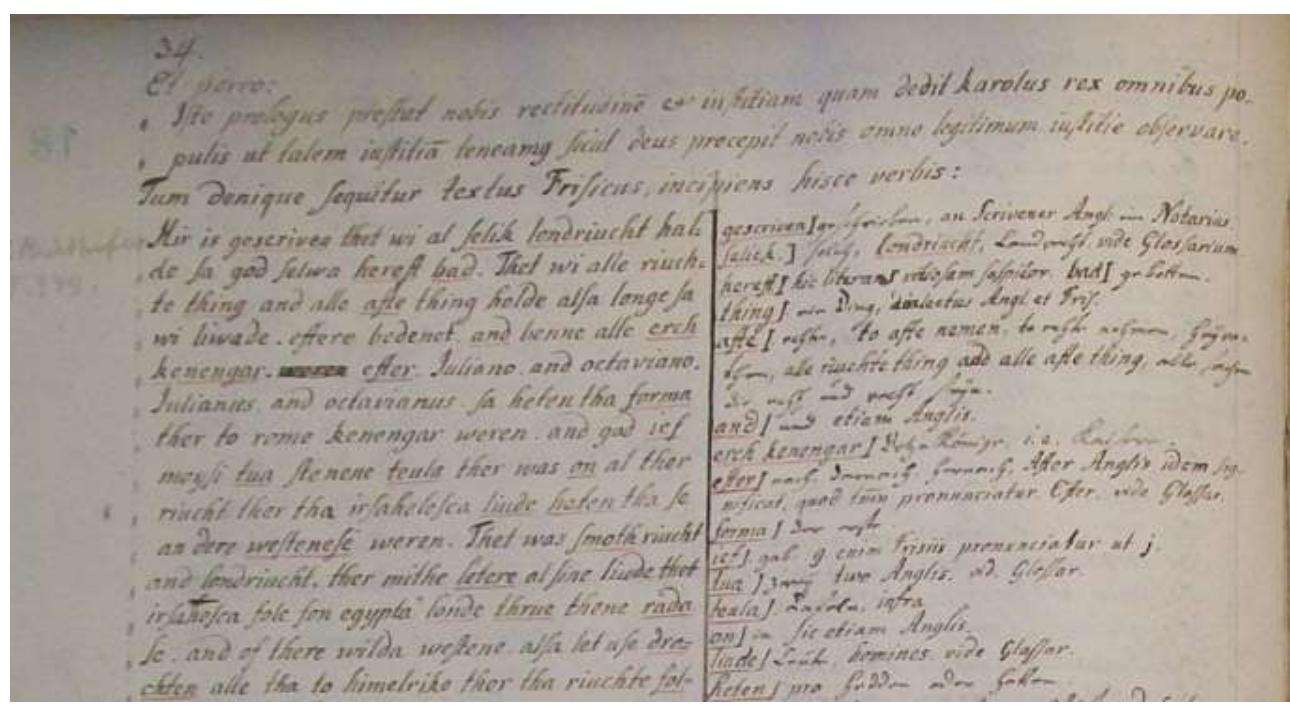

S. 41-83, Fol. 22r-42r Alfabetisch glossarium op de Friestalige stukken in Schotanus

S. 84, Fol. 42v Lijst van munten in de Friestalige stukken in Schotanus

Los voorin het handschrift (S. 1a, Fol. 1r) ligt een concept of afschrift van een Friestalige brief (met gedeeltelijke Franse interlineaire vertaling) in de hand van Von dem Appelle, geschreven door 'jon e. tjenneres' aan 'myn greate stalcke, in heag geachte meegh, tha Heera v. Kr., fioerste tjenner fen the Broer fen the Konige fen Pruessen to Berlin', gedateerd 'Emden, de tua in twyntigste dey in hea moanne' [22 juli]. Op deze merkwaardige brief wordt hieronder nader ingegaan.

Het handschrift is niet alleen interessant omdat het getuigt van de vondst van $\mathrm{H} 1$ en de bezitsgeschiedenis daarvan enige decennia verder terugvoert, maar ook omdat het inzicht geeft in de lexicografische en vertaalarbeid die Von dem Appelle zich getroostte door zonder enig voorbeeld of woordenboek Oudfriese teksten te ontcijferen en te duiden. Een drietal teksten (Willekeuren van de Opstalsboom, Tractaat van de Zeven Zeelanden, Willekeuren van Wildinge) schreef hij over om te vertalen. Hij maakte een alfabetisch glossarium op alle Oudfriese woorden die hij bij Schotanus vond, en noten met woordverklaringen bij de tekst van de Hunsingoër Keuren van 1252 in H1. Dit laatste apparaat heeft hij slechts ten ten dele voltooid. ${ }^{60}$ Het

60. Beide glossaria zijn hieronder als bijlage opgenomen. 
lijkt erop dat hij abrupt de pen heeft neergelegd, halverwege de vertaling van de Willekeuren van Wildinge en het annoteren van $\mathrm{H} 1$.

De glossaria die Von dem Appelle op Schotanus en H1 vervaardigde, passen geheel in de belangstelling van zijn tijd. Verschillende woordenlijsten en glossaria, al of niet voltooid, hebben we hiervoor al ontmoet en hierna zullen er nog enkele volgen. Bijzonder is vooral dat het resultaat van Von dem Appelle ook overgeleverd is, waar die ons bij de meeste anderen onbekend zijn. Inhoudelijk is zijn glossarium overigens wel veel beperkter dan het Vocabularium Frisicum glossatum van Matthias von Wicht. ${ }^{61}$ Ook dit Oudfriese woordenboek, een kleine halve eeuw vóór dat van Wiarda samengesteld, is in de literatuur onbekend gebleven, net als Von Wichts overige handschriftelijke nalatenschap van de hand van zijn zoon, waaruit we in het vervolg nog uitgebreid zullen putten.

\section{Het Landrecht van graaf Edzard}

In het handschrift 'Iuris Provincialis Frisiae Orientalis collatio ex diversis manuscriptis' analyseert Von dem Appelle verschillende exemplaren van het Oost-Friese Landrecht. Hij begint met een beschrijving van de inhoud van de Codex Emdanus (1571), die hem in 1728 door het Emder stadsbestuur ter beschikking was gesteld. Vervolgens wijdt hij nog enige woorden aan het schrift en de mogelijke schrijver van het handschrift:

Hrr. Pastor Eilh. Folckard Harckenroth, dem ich dieses geschriebene Landrecht gezeiget, meinete daß der Caracter solcher Schriftt völlig übereinkäme mit einigen geschriebenen Briefen Hadriani Hamstedii, die er in Handen hätte; Es ist dieser Adrianus Hamstedius ein Niederländer, und wie Hrr. Haase in Fascic. Bremens. Cl. 5 fasc. 4 p. $715^{62}$ meldet, ein Seeländer, und zu Zeiten der Reformation ein eiferiger Theologus gewesen, der zu Beförderung der Reformation von der Kirche zu Emden nach Antwerpen, Aachen, Groninngen und London gesandt, wie an besagten Orth weitläuffiger gemeldet worden, daselbst meinet aber ged. Hrr. Haase daß er Anno 1562 in Friesland verstorben, welches jedoch nicht seyn könte, wann er dieses Buch solte geschrieben haben, alß welches Ao. 1571 geschehen, unterdessen kommen die Buchstaben zu Ende dieses MS. wie oben gezeiget hiermit gar wohl überein.

61. Een uitgave wordt voorbereid door Riemer Janssen, Anne Popkema en schrijver dezes.

62. Bibliotheca historico-philologico-theoogica. Classis quintae fasciculus quartus (Bremen 1721), Excerpta ex literis Eil. Folc. Harckenrothii ad Theod. Hasaeum, 707-727, ald. 715 , noot $\mathrm{c}$. 
Met zijn bedenkingen over de schrijver van de Codex Emdanus zat Von dem Appelle in de goede richting, maar het verband is juist andersom: Adriaen van Haemstede overleed wel degelijk in 1562 en kan daarom onmogelijk de schrijver van het handschrift zijn geweest. Ik heb dit fragment uitgebreider aangehaald omdat het Von dem Appelles kritische benadering van zijn bronnen illustreert. In de tweede helft van zijn handschrift analyseert hij de verschillen tussen de Codex Emdanus en zijn eigen afschrift van het exemplaar van het Hofgericht, ${ }^{63}$ welkt origineel voor hem inmiddels onbereikbaar was geworden sinds zijn ontslag in 1724 .

Eilhardus Folkardus Harkenroth, met wie Von dem Appelle van gedachten wisselde over de schrijver van de Codex Emdanus, was predikant te Emden. Tegenwoordig is hij vooral bekend door zijn uitgave van de kroniek van Eggerick Beninga in 1723. Eilhardus en zijn al even productieve broer Jacobus Isebrandus (1676-1736), predikant in Appingedam, correspondeerden regelmatig met Von dem Appelle over historische of genealogische zaken. Dat zij intensief contact met hem hadden, is niet verwonderlijk in het licht van het Oost-Friese politieke schisma. In het eerste kwart van de achttiende eeuw was kanselier Enno Rudolph Brenneysen een ijverig voorvechter van een absolute regering van de graven. In geschriften richtte hij zijn pijlen op de al bijna een eeuw eerder overleden Ubbo Emmius en diens conclusies over de verhouding tussen grafelijkheid en standen. Jacobus Harkenroth stelde zich daartegen teweer en raakte daardoor sinds de eerste uitgave van zijn Oostfriesche oorspronkelijkheden in 1712 verwikkeld in diverse processen over zijn publicaties. In 1722 verruilde hij daarom de kerk te Larrelt voor die van Appingedam. Niet verwonderlijk dat we onder de handschriften van Von dem Appelle ook geschriften van de gebroeders Harkenroth vinden, ${ }^{64}$ processtukken in de processen tussen de graaf en Jacobus Harkenroth $^{65}$ en correspondentie met hem. ${ }^{66}$

Alles wijst erop dat Von dem Appelle deze collatio van het Oost-Friese landrecht al vrij kort na 1728 heeft samengesteld, toen hij in Emden verbleef en inzage kreeg in de Codex Emdanus. Dit wordt ook bevestigd door het sterfjaar (1736) van Eilardus Harkenroth. Het werk heeft na de uitgave van Von Wicht natuurlijk veel van zijn waarde verloren, maar het blijft inter-

63. Dep. 1 Msc, inv.nr. 62. Dit eigen exemplaar van het Landrecht, dat omstreeks 1797 aan de Landschaft werd overgedragen (Alma, 'Grimersumer Kiste', 365), is nog niet teruggevonden. Het originele exemplaar van het Hofgerecht is wel bewaard gebleven.

64. Dep. 4 IX, inv.nr. 24

65. Dep. 4 IX, inv.nr. 22 en 23.

66. Dep. 4 IX, inv.nr. 10a. 
essant omdat het enig zicht geeft op het netwerk van Von dem Appelle en ook op zijn tekstkritische vaardigheid in de vergelijking van de twee handschriften.

Net als ten aanzien van de meeste van Von dem Appelles handschriften is het moeilijk vast te stellen in welke fase van zijn lange leven hij dit samengesteld heeft. Veel van zijn verzamelwerk, zowel van handschriften als van teksten en wapens op objecten, lijkt in de jaren tien en twintig van de achttiende eeuw te zijn verricht. Na het uitbreken van de Appelle-Krieg en zijn daaropvolgende ballingschap lijkt zijn Oud-Friese juridische interesse verflauwd te zijn. Hij moet op een gegeven moment geweten hebben van de ontdekking van R1, toen hij de Memoria Stadeniana uit 1725 in handen kreeg, maar hij maakt bij mijn weten nergens melding van R1, zelfs niet bij het lemma 'Aasdoem, Asigadoem' in zijn Collectanea etimologiae linguae Germanicae ${ }^{67}$ ondanks dat hij op dat moment de Memoria Stadeniana al wel kende. ${ }^{68} \mathrm{Zijn}$ interesse in toponiemen en de etymologie daarvan was echter blijvender.

Dit alles overziende kom ik tot de conclusie dat Von dem Appelles werkzaamheden op het terrein van de Oudfriese rechtsbronnen beperkt is gebleven tot ca. 1730. De reden daarvoor lag, naar ik vermoed, in de activiteiten van de volgende speler op dit podium: Matthias von Wicht.

\section{Matthias von Wicht}

De activiteiten van Von Wicht op het terrein van het Oudfriese recht zijn door hemzelf uitgebreid gedocumenteerd in zijn uitgave van het Oost-Friese Landrecht uit 1746. In de literatuur is dat ook de enige gebruikte bron voor zijn werkzaamheden. In Oost-Friese archieven en bibliotheken is echter meer van zijn schriftelijke nalatenschap bewaard gebleven dat inzicht geeft in zijn activiteiten op dat terrein. Om de relatie met Von dem Appelle te bepalen en diens rol in een bredere context te plaatsen zullen we daar dankbaar gebruik van maken.

Von dem Appelle en Von Wicht hadden veel gemeenschappelijk. Zij waren geboren Oost-Friezen, generatiegenoten en bereikten beiden een hoge leeftijd. Zij hadden een brede interesse, die op het gebied van de historische taalkunde en in het bijzonder met betrekking tot het Fries overlapte. Aan een aantal voorwaarden voor een vruchtbare samenwerking was dus voldaan.

In 1719 schreef Matthias von Wicht een verhandeling over de vraag of

67. Dep. 4 IX, inv.nr. 12, pag. 44, fol. 21v.

68. Dep. 4 IX, inv.nr. 12, pag. 16, fol. 8v. 
paus Leo III aan de Friezen het zeendrecht gegeven had. ${ }^{69}$ In dit stuk maakt hij enkel gebruikt van gedrukte bronnen, met name Siccama ${ }^{70}$. Hij promoveerde in 1724 in Groningen op een dissertatie over ultimogenituur in het Oost-Friese recht. ${ }^{71}$ In hetzelfde jaar culmineerde de strijd tussen de vorst van Oost-Friesland aan de ene kant en de Oost-Friese standen en de stad Emden aan de andere kant op 23 november in het ontslag van het administratorencollege in Emden en de inrichting van een nieuw college in Aurich, namens de 'gehorsame Stände'. Op 27 juli 1725 trok Von dem Appelle zich, na een mislukte poging om hem gevangen te nemen, in Emden terug, waar de administratoren namens de 'renitente Stände' bleven optreden. Matthias von Wicht trad in 1726 in dienst van het concurrerende college in Aurich en publiceerde in hetzelfde jaar een Accordenmäßige Gegenanweisung des ... Unfugs deren Renitenten in Puncto Submissioni. ${ }^{72}$ Men kan zich voorstellen dat daarmee geen goede basis gelegd werd voor een vriendschappelijke correspondentie met Von dem Appelle, die lange tijd van amnestie werd uitgesloten en nog vele jaren in ballingschap zou verblijven. Een vruchtbare uitwisseling op basis van hun gemeenschappelijke interesse heeft dan ook niet plaatsgevonden.

Toch heeft Von Wicht kennisgenomen van de ontdekking van H1 door Von dem Appelle en diens extract gebruikt. Het afschrift dat Von Wicht daarvan maakte, is bewaard gebleven en zijn gelijknamige zoon heeft hierbij, na zijn vaders dood, de bron vermeld:

Extract aus einem alten Landrecht von Hunsingo, welches den Grafen von Nienoort zugehörig gewesen, jetzt aber in unbekannten [i.m.: vermuthl. bey dem Groningischen Bürgermeister Gerdes, ${ }^{73}$ ehemaligen

69. Dep. 1 Msc, inv.nr. Q 153, fol. 1r-27r. Zijn auteurschap blijkt uit verwijzingen op fol. 8v. Zie ook Von Wicht, Ostfriesische Land-Recht, Vorbericht, 136-140, waar hij voor verdere behandeling verwijst naar zijn nog te verschijnen Historia Juris Frisici.

70. De aangehaalde Oudfriese tekst in Dep. 1 Msc, inv.nr. Q 153, fol. 20v, is ontleend aan Siccama, Lex Frisionum, 131-132

71. M. von Wicht, De Origine et Causa Statuti Ostfrisici, quo Fratri Minori Sedes Paterna, prae Majoribus Natu Possidenda, in Successione relinquitur (Groningen 1724) 24 pag.

72. Gedrukt te Oldenburg in 1726. W. Deeters, 'Matthias von Wicht', in: M. Tielke (red.), Biographisches Lexikon für Ostfriesland I (Aurich 1993) 365-366.

73. Hier moet een vergissing in het spel zijn. Een burgemeester van die naam bestond niet. Wellicht is er verwarring met de Landrichter Henricus Gerdes († 1602), wiens Codex Emdanus aan de stad Emden geschonken werd, waarin Von Wicht op 24 maart 1735 inzage verzocht. Stadtarch. Emden, Reg. I, inv.nr. 289. Zie Von Wicht, Ostfriesische Land-Recht, Vorbericht 202. 
Vormund der jungen Grafen v. Nienoort] Händen ist, so wie der H. H.B. von dem Appele selbiges eigenhändig abgeschrieben hat.

(Es ist dieser Auszug in den Anmerkungen zum Ostfriesischen Landrechte (im Vorbericht S. 56sq. und S. 147f. und unter dem Landrechte selbst S. 829f.) schon durch den Druck bekannt gemacht. Vollständig ist es abgedruckt in dem II $^{\text {ten }}$ Bde. der Verhandelingen der (groning.) Genootschap pro excolendo jure patrio, $178 \ldots{ }^{74}$ (S. Wiarda Vorber. zu seinem Fries. Wörterb. ${ }^{75}$ S. 45) ohne Uebersetzung und Erlauterungen jedoch nach einem andern, von gegenwärtigem etwas verschiedenem Manuscript, und welches, wenigstens in dem Abdrucke, von Schreibfehlern vollstrecken soll... Die eigen Handschrift dieses Auszugs von H. v.d. Apele ist bey mir gleichfalls noch vorhanden)

M. v. Wicht, jun. ${ }^{76}$

Matthias sr. besteedde in zijn Ostfriesisches Landrecht (1746) uitgebreid aandacht aan het handschrift. Hij begint zijn bespreking met een verwijzing naar Emmius over de Hunsingoër Keuren van $1252,{ }^{77}$ waaruit hij concludeert dat 'allem vermuthen nach' Emmius het handschrift zelf gezien en gebruikt moet hebben. ${ }^{78}$ Die conclusie is niet geheel juist, want Emmius bezat het handschrift $\mathrm{H} 2$ en niet $\mathrm{H} 1$.

Emmius hat hierin der Wahrheit gemäß, und aus dem Document oder dem Rechts-Buch selbst geschrieben; Denn anderwärts findet man davon keine Nachricht. Ob wir zwar daß Buch selbst bishero nicht zu sehen bekommen können, so wissen wir doch von sehr guter Hand, daß es noch an einem sicheren Orte in Grönninger Lande vorhanden sey, und wir sind von einem vornehmen Augenzeugen, der es auf Pergament geschrieben in Händen gehabt und einen sorgfältigen Auszug daraus gemacht, in Stand gesetzet, dem geneigten Leser einen weit ausführlicheren Bericht, als man von obbelobten Emmius, nach der Beschaffenheit seines Zweckes, fordern kan, davon in der unten gesetzten Anmerckung zu erstatten d). [In deze noot weidt Von Wicht verder uit over de inhoud]. ${ }^{79}$

'Ein vornehmer Augenzeuge', zo noemt Von Wicht zijn naamloze zegsman, die het handschrift in handen heeft gehad, een zorgvuldig extract vervaar-

74. Lees: '1778'.

75. Verschenen in 1786.

76. Dep. 1 Msc, inv.nr. Q 150, fol. 148r.

77. Ubbo Emmius, Rerum frisicarum historiae (Leiden 1616) 152-153.

78. Von Wicht, Ostfriesische Land-Recht, Vorbericht, 100.

79. Von Wicht, Ostfriesische Land-Recht, Vorbericht, 147. 
digde en Von Wicht in staat stelde om er uitvoeriger verslag van te doen. Ook verder zoeken we de naam van Von dem Appelle tevergeefs in het 1.170 pagina's tellende Ostfriesische Land-Recht. Door het magnum opus van Von Wicht is $\mathrm{H} 1$ onder de geleerden bekend geworden, zozeer dat het originele handschrift de naam 'Ms. Wicht' heeft gekregen, wat des te merkwaardiger is omdat hijzelf het nooit gezien heeft. Pas na zijn dood kwam het handschrift in 1781 weer in het vizier, toen het door D.F.J. van Halsema gekocht werd. Dat was drie jaar na diens editie van $\mathrm{H} 2$, waaraan hij de varianten van $\mathrm{H} 1$ nog naar de editie van Von Wicht had moeten toevoegen. ${ }^{80}$ Maar, ere wie ere toekomt, de eerste die het belang van H1 onderkende, was Von dem Appelle in 1716.

\section{Matthias von Wicht op zoek naar rechtshandschriften}

Wanneer precies Von Wicht het afschrift van H1 in handen heeft gekregen, heb ik niet kunnen vaststellen. Het kan al vrij snel na de ontdekking geweest zijn, toen de politieke situatie in Oost-Friesland nog niet ontspoord was, dus vóór 1724.

Rond 1732 - het precieze jaartal is mij nog niet bekend geworden - kreeg Von Wicht opdracht om het Oost-Friese landrecht uit te geven, opdat 'das bisdahero in Manuscripto gelegene ostfriesische Landrecht und zwar nach dem beym hochloblichen Hoff-Gerichte verwahrlichen und mir zusolchem Ende gütigst communicirten Original-Exemplar, nebst einer accuraten Übersetzung ins Hoch-Teutsche, Erklährung der alt-friesischen fast unbekant gewordenen Wörter, Variantibus Lectionibus, Marginalien und nöthigen Registern zum Druck befordert werde und damit bereits ein ziemlicher Anfang gemacht worden'. Hij schrijft dit in een brief van 24 maart 1735 aan het stadsbestuur van Emden, waarin hij verzoekt de Codex Emdanus te mogen lenen. ${ }^{81}$

De oplettende lezer zal zijn opgevallen dat de aangehaalde exemplaren van het Oost-Friese Landrecht dezelfde zijn als die waar Von dem Appelle in of kort na 1728 zijn collatio mee samenstelde. Ook hij baseerde zich op het exemplaar van het Hofgerecht als het basishandschrift en vergeleek dit met de gezaghebbende Codex Emdanus. Het heeft er alle schijn van dat Von dem Appelle zich aan dezelfde arbeid heeft gewijd als Von Wicht, maar dan in opdracht van de 'renitente' standen.

80. Van Halsema, Aloude Ommelander wetboek. Zie verder J. Hoekstra, De Eerste en de Tweede Hunsinger Codex ('s-Gravenhage 1950) 7, 19.

81. Stadtarch. Emden, Reg. I, inv.nr. 289. 
De eerste dateerbare activiteit van Von Wicht in het kader van zijn opdracht was zijn aankoop van het Eerste Brokmer Handschrift in mei 1732 (gekocht van de Norder conrector Albert Christian Andreae). ${ }^{82}$ Hij beschrijft het verworven handschrift in 1746, met duidelijke trots: 'Wir besitzen davon ein Original, und halten es für das eintzige, so in Ostfriesland $\mathrm{zu}$ finden ist. $^{83}$

E3 was volgens eigenhandige inschrijvingen eigendom van Ernst Friedrichs van Wicht (1548-1602), een broer van de betovergrootvader van Matthias von Wicht. Of de laatste er direct en door vererving de beschikking over had, weten we niet. Hij laat zich er niet expliciet over uit. Ook van B1 neemt hij aan dat het eigendom van Ernst Friedrichs geweest is, 'und beydes ist endlich wiederum an uns gekommen' ${ }^{84} \mathrm{Hij}$ vermoedde dat andere Emsiger handschriften wel niet meer zouden bestaan; hij had ze in elk geval niet gezien. ${ }^{85}$

Eveneens in 1732 vatte Von Wicht de zoektocht naar R1 weer op, die een jaar of twintig stil had gelegen. We zijn over het verloop daarvan redelijk goed ingelicht doordat hij verschillende brieven afgeschreven heeft. ${ }^{86}$ De correspondenten zijn meest inwoners van Butjadingen en Wursten. Als eerste richtte men zich op de tekst die Schroetern gekend had, waarvan onduidelijk was of dat het origineel was of enkel een afschrift. Op 27 september 1732 schreef Von Wicht een brief, voorzien van een volmacht van Schroeterns schoonzoon, om het afschrift, dat was geleend door Eckhart en niet teruggegeven, alsnog in handen te krijgen. ${ }^{87}$

De interesse blijkt breed gedeeld te worden. Er waren meer exemplaren van het Asegaboek, zoals het Rüstringer handschrift consequent genoemd wordt, in omloop, 'jedoch in plattdeutscher Sprache', zo meldt Siebrand Meyer (1694-1776) ${ }^{88}$, predikant te Esenshamm in Butjadingen, aan assessor Johann Schnedermann (1700-1767) te Aurich, die blijkbaar als tussenper-

82. W.J. Buma, Die Brokmer Rechtshandschriften ('s-Gravenhage 1949) 1*.

83. Von Wicht, Ostfriesische Land-Recht, Vorbericht, 154-165. B2 is pas later door Oelrichs ontdekt. Buma, Brokmer Rechtshandschriften, 11*.

84. Von Wicht, Ostfriesische Land-Recht, Vorbericht 167. K. Fokkema, De Derde Emsinger Codex ('s-Gravenhage 1959) 3.

85. Von Wicht, Ostfriesische Land-Recht, Vorbericht 166. E1 en E2 zijn na Von Wichts dood verworven door Wiarda en eerdere bezitters zijn onbekend. P. Sipma, De Eerste Emsinger Codex ('s-Gravenhage 1943); K. Fokkema, De Tweede Emsinger Codex ('sGravenhage 1953) 2.

86. Dep. 1 Msc., inv.nr. Q 153, fol. 237v-249r.

87. Dep. $1 \mathrm{Msc}$, inv.nr. Q 153, fol. 242v.

88. Zijn leefjaren worden verschillend opgegeven. 
soon tussen deze predikant en Von Wicht fungeert. Conrad Wierichs (16821745), geboren te Abbehausen, schrijft Von Wicht op 22 september 1733 dat hij twijfelt of in Butjadingen een exemplaar 'in friesischer Sprache' voorhanden is. Hij schrijft verder dat '[ich] von Jugend auf, sehr nachgeforschet habe, um etwas gedrucktes oder geschriebenes in dieser Sprache ... zu haben und solche verstehe zu lernen'. Zijn grootmoeder en tevens die van zijn neef, assessor Eilerd Ilcksen (1698-1740), geboren te Brunswarden bij Rodenkirchen, was Emme Elksen uit Langemene (ondergegaan in de Wezer bij de Kerstvloed van 1717). Zij was in de herfst van 1689 overleden en had de oude taal nog gesproken. Wierichs' ouders hadden nog een knecht die 'davon im Lande Wursten etwas gefaßt hatte', maar dat had hem niet verder geholpen. Later had Wierichs de Noord-Friese kroniek van Heimreich $^{89}$ en het boek van Siccama in handen gekregen, waarin 'Frisica' opgenomen zijn. In de kerk van Abbehausen zal in elk geval geen Asegaboek zijn, anders had hij het wel gehoord. Des te meer twijfelt hij aan het bestaan omdat Anton Höting, landrichter te Ovelgönne, rond 1652-1664 bericht dat onder de onderdanen geen compleet exemplaar meer aanwezig was. Wel had Höting zelf een 'Jeverisches Exemplar des friesischen Landrechts', 90 maar dat was al 'deutsch gewesen, weil die Sprache schon in diesen Gegenden vergessen war'. 91

Een andere correspondent van Von Wicht, Eide Siade Johans (†1760) uit Wursten, sinds 1725 richter te Lehe, was zelf een liefhebber van de 'alte friesische Sprache', waarvan hij een Vocabularium had samengebracht. Hij schrijft op 5 maart 1735 dat buiten kijf is dat in alle Friese landen Fries gesproken werd, al zal men tussen het West-Fries en het Noord-Fries veel verschillen zien. In het land Wursten wordt nog door weinigen 'Friesisch' gesproken. Hij kent de Bolswarder rector en dichter Johannes Hilarides. De incunabel van het oude Friese landrecht heeft hij nooit gezien. Het oude Friese recht heeft volgens hem ongetwijfeld ook in Wursten gegolden. Men heeft aldaar nog wel een 'altes Asingsbuch', maar dat is niet in het Fries. Wel weet hij dat enige jaren geleden op een veiling te Bremen een 'ziemlich

89. Antonius Heimreich, Nord-Fresische Chronick (Sleeswijk 1666).

90. Bevattende 'die 17 Koeren oder Kesten, die 24 Landrechte, die 6 Overkoere, 12 Emsinger Dome, nebst andere Specialibus'. Zie verder Borchling, Niederdeutschen Rechtsquellen, LXXVII-C.

91. Dep. 1 Msc., inv.nr. Q 153, fol. 239v. 
alter Codex Friesischer Gesetze' verkocht is, die door de archivaris Post ${ }^{92}$ is verworven. ${ }^{93}$

Enige jaren later, in elk geval vóór $1738,{ }^{94} \mathrm{kreeg}$ Von Wicht door bemiddeling van de genoemde assessor Ilcksen een afschrift van het origineel in het Oldenburger archief in zijn bezit. ${ }^{95}$ Intussen kondigde Ernst Joachim von Westphalen (1700-1759) in zijn voorwoord op het eerste deel van zijn Monumenta in 1739 de uitgave van het 'Asighebock' aan in het volgende deel, maar de vierdelige serie wordt tot Von Wichts teleurstelling zonder dat resultaat afgesloten. ${ }^{96}$ Uiteindelijk kreeg Von Wicht op 24 augustus 1745 bericht dat het origineel hem binnen een paar weken toegezonden zou worden; men was overigens wel huiverig het 'außer Lande', dus buiten het land Oldenburg, te sturen. Op 25 september 1745 bevestigde hij de ontvangst ${ }^{97}$ en kon hij zelf het afschrift collationeren. ${ }^{98}$ In zijn Ostfriesische Land-Recht, waarvan de druk een jaar later eindelijk voltooid werd, kon hij de resultaten nog maar deels verwerken. ${ }^{99}$

Ook Von Wichts andere activiteiten om Oudfriese rechtsbronnen te ontsluiten vonden in deze periode plaats. In 1738 vervaardigde hij een vertaling van Druk. ${ }^{100}$ Het origineel had hij tot zijn leedwezen nooit gezien en hij moest het dan ook doen met de uitgave door Schotanus. ${ }^{101}$ Dat weerhield hem er overigens niet van er een uitgebreide verhandeling aan te wijden. ${ }^{102}$ In hetzelfde jaar 1738 voltooide hij ook nog eens een bespreking van de Friese bronnen in de Bodleian Library. ${ }^{103}$

De activiteiten van Von Wicht vanaf 1732 verklaren afdoende waarom Von dem Appelle zijn Oudfriese juridische werkzaamheden heeft stilgelegd om nooit meer op te pakken. Hij hield zich met andere zaken onledig en had

92. Hermann (von) Post (1693-1762), archivaris van de stad Bremen.

93. Dep. 1 Msc., inv.nr. Q 153, fol. 270v-271v.

94. Dep. 1 Msc, inv.nr. Q 153, fol. 230v.

95. Dep. 1 Msc, inv.nr. Q 151, pag. 1. Dit zal is vermoedelijk het afschrift in Dep. 1 Msc, inv.nr. 75, fol. 1r-52v.

96. E.J. von Westphalen, Monumenta inedita rerum Germanicarum praecipue Cimbricarum et Megapolensium I (Leipzig 1739) praefatio 122. Zie Dep. 1 inv.nr, Q 153, fol. 59v, d.d. 7 aug. 1745.

97. Dep. 1 Msc, inv.nr. Q 153 , fol. 243 r en $247 \mathrm{v}$.

98. Dep. 1 Msc, inv.nr. Q 151, pag. 1-106.

99. Von Wicht, Ostfriesische Land-Recht, Vorbericht 170-176 en tekst 434.

100. Dep. 1 Msc, inv.nr. 75, fol. 55r-129v. Dep. 1 Msc, inv.nr. Q 150, fol. 1r-147r.

101. Von Wicht, Ostfriesische Land-Recht, Vorbericht 144. Dep. 1 Msc, inv.nr. Q 153, fol. 270v.

102. Dep. 1 Msc, inv.nr. Q 153, fol. 230r-233v.

103. Dep. 1 Msc, inv.nr. Q 153, fol. 234r-235v. 
genoeg interesses om zijn tijd mee te doden, door het uitwerken van verzamelde gegevens in fraai gekalligrafeerde handschriften. Op de titelpagina van zijn Chronologia Frisiae Orientalis dateert hij het werk met het chronogram 'eXILIVM LIbertatIs CaVsa obDVrantIs' (1729), in ballingschap volhardend omwille van de vrijheid.

\section{Het glossarium linguae vulgaris sive rustica Frisiae orientalis}

In het voorgaande zijn we niet alleen ingegaan op de zoektocht naar Oudfriese rechtsbronnen, maar hebben we ook uitgebreid de verwijzingen naar gesproken Fries geciteerd om de activiteiten van Von dem Appelle op dat terrein in een context te plaatsen. Diens interesse in het (Oud)fries was minder rechtshistorisch dan wel taalkundig. Met name etymologie en samenhang tussen verschillende talen had zijn aandacht, waarbij hij ook de gesproken taal als bron gebruikte. Net als bij de eerdergenoemde geleerden en liefhebbers is zijn aanduiding van talen en dialecten niet eenvoudig te interpreteren. Volgens Von dem Appelles bibliotheekcatalogus heeft hijzelf een glossarium van de gesproken taal van Oost-Friesland samengesteld, dat helaas niet overgeleverd is, of althans onvindbaar is: het Glossarium linguae vulgaris sive rustica Frisiae orientalis sive Samlung etc. ${ }^{104}$ Het is de vraag wat voor taal daarin beschreven is geweest. Om die vraag te beantwoorden richten we ons op de verwijzingen naar de gesproken taal in zijn 'Collectanea etimologiae linguae Germanicae'. ${ }^{105}$

- 'Es ist solches auch noch heutigen Tages im Plat-Deutschen, in Flandern und Friesland bekand, da man noch heutiges Tages Kötteren, Kedderen, Quettern saget. Am letzten Orth aber ist unter dem gemeinen Mann das Wort Questhen, Questern mehr dann zu bekandt.' 106

- 'So sagen auch wir Niedersachser noch wann wir und über etwas Singulaires verwundern: dat is drolich, die die Frantzosen c'est bien drôle. ${ }^{107}$

- 'Atta, so im alten Teutschen einen Vater bedeutet ... Welcher Nahme im Friesichen noch die Stunde gebräuchlich, da Atte, Ayte, oder auch cum aspiratione Haite einen Vatter bedeutet, und nicht nur von der Kinderen gesaget wird myn Aite, myn Memme, mein Vatter, meine Mutter, sondern

104. Dep. 4 IX, inv.nr. 63, pag. 191: H.B. v. Appell, Glossarium linguae vulgaris s. rustica Frisiae orientalis $s$. Samlung etc.

105. Dep. 4 IX, inv.nr. 12.

106. Fol. 4v, s.v. 'Quethen'.

107. Fol. 11r, s.v. 'Drol'. 
auch das Gesinde nennet den Haußwirth Haite, und andere wann sie einen alten Bauer ehren wollen, sprechen ihn an: haite, wie man in Teutschland Vatter zu einem solchen saget.' 108

- 'Von können kombt noch her Kunst oder nach dem holländischen dialecto Konst, gleichwie von gönnen Gunst, von brennen Brunst., 109

- 'Das friesische Wort Hovetling ...,110

- 'Das Wort baren, gebähren, gignere, wie die Niederländer noch sagen baaren. Barm heißet bey demselben die Geburth, puerperium, barida, germinans. ... Daher heißet fast in allen alten teutschen Dialectis bern, ein Kindt, ... bey den Friesen bern. ${ }^{111}$

- 'Das nunmehr ungebräuchliche Worth Quick oder Queck bedeutet eigentlich ein lebendieges Thier und ist eigentlich in denen letzteren Zeiten gebraucht vor zahmen oder Haußvieh als Pferde, Kühe, Sweine, Schafe, etc. ... In denen meisten Dialecten der teutschen Sprach sind hiervon reliquia: quicke bedeutet bey denen Niederländer, bey den Engelländer qwick, ... lebendig., 112

- 'Die Friesen nennen einen Schneider, Schro. Dieses ist auch ein platdeutsches Wort, vide Henr. Ep. Verd. Capituli et Senatus Verd, Vergleich de 1371 ,113

- 'Hesse bedeutet von Alters eine Catze, wird auch noch davor an etzlichen Ortern Teutschlandes gebrauchet; auch bey uns ist unter dem gemeinen Mann noch üblich ein böses und dreistes Weib eine böse Hesse zu nennen. ${ }^{, 114}$

- 'Aha ... In Friesland wo das $a$ wie ein $a$ oder $e$ pronunciret wird, ist die Beteutung dieses Wortes in Ehe beygeblieben... Und die itzige niederdeutsche Benennung einer Insull Eiland ist auch nicht anders alß Wasser-Land.' 115

- 'Vox Hore significat lutum, coenum, terram humidam et huc illuc pedibus versatilem. ... Bey uns ist dieses Worth in einen Stück noch üblich: der Koth welcher aus denen Graben oder Sloten, auf den nechsten

108. Fol. 18v, s.v. 'Od, Edel, Edelmann'.

109. Fol. 19r, s.v. 'Konig'.

110. Fol. 19v, s.v. 'Ling, Hovetling, Sterling'.

111. Fol. 23v, s.v. 'Gebären, Baren, Born, Harren, Pferd'.

112. Fol. 24r, s.v. 'Quick, Queecken, Quicksilber, Quicksteert, Keck'

113. Fol. 28v, s.v. 'Schroeder'.

114. Fol. 29v, s.v. 'Hesse'.

115. Fol. 31r, s.v. 'Ohge, Ey, Insull, Eyland'. 
Wall geworffen wird bey dem Ausgraben, oder einigen derselben, wird Dat Horr genandt,. ${ }^{116}$

- 'Loh ... Einige wollen auch das friesische Wort Loog, Loeg, daher deriviren, welches ein Dorff bezeignet, auf zusammengebrachte, aufgeführete Hügell erbauet sind.' 117

- 'Ade heist noch heutiges Tages in der alten friesischen oder dauren Sprache, so viel als Alt, vetus. 118

Ik heb deze citaten letterlijk overgenomen, omdat eruit blijkt hoe lastig het is om te bepalen wat Von dem Appelle precies bedoeld met 'friesisch', 'niederdeutsch', niedersächsisch', 'holländisch', 'niederländisch' of 'bey uns'. Tekenend voor de verwarring, die we hierboven ook al bij de vroegachttiende-eeuwse geleerden aantroffen, is het laatste citaat, waar wordt gerefereerd aan de 'alte friesische Sprache' die 'heutigen Tages' gebruikt wordt, wat overkomt als een contradictio in terminis. 'Alt Friesisch' is duidelijk iets anders dan 'Altfriesisch'.

Matthias von Wicht stelt, onder verwijzing naar Gabbema's inleiding bij Gysbert Japicx' Rymlerye, ${ }^{119}$ dat tot 1300 de 'altfriesische Sprache' nog in Westfriesland (het huidige Friesland) in zwang gebleven is en trekt (ten onrechte) de conclusie dat het Fries daar toen verdwenen is. Daarentegen zou 'in unserem Ostfriesland, insonderheit in Harlingerland' deze taal 'fast länger' bewaard gebleven zijn dan in Westfriesland, zoals zou blijken uit de Historia Werdumana en het Memoriale van Müller. Volgens Von Wicht komt dat doordat Harlingerland langer onder eigen, inheemse heren is gebleven, zoals blijkt uit het oude perkamenten Emsiger landrecht van 1312, dat hijzelf bezit. Toch wordt in Gabbema's inleiding nog Furmerius aangehaald dat de 'alte Sprache' nog in 1547 gesproken werd, 'wiewol nicht durchgängig'. Harkenroth vermeldt in 1712 s.v. Potshausen dat aldaar het 'Altfriesische' nog wordt gesproken, net als in Molkwerum in Westfriesland. ${ }^{120}$ Von Wicht heeft een 72-jarige man, Cornelis Berens, in Pots-

116. Fol. 34v, s.v. 'Hore'.

117. Fol. 35v, s.v. 'Loh'.

118. Fol. 36v, s.v. 'Ade'. Het woord 'dauren' kan ik niet met zekerheid lezen.

119. Gysbert Japix, Friesche Rymlerye, dl. 1 (Leeuwarden 1681) XXIII (paginering volgens Von Wicht; in editie ongepagineeerd).

120. J.I. Harkenroht, Oostfriesse oorsprongkelijkheden (Emden 1712) 152, s.v. Potshuuzen: 'Dit dorp ligt aan een arm van de Versse Eems, loopende in het Munstersse Saderland, alwaar de Oude Friesse taale nog op heden, gelijk te Mulkwerum in Friesland, gesprooken word.' Het is dus de vraag of Harkenroth duidt op Potshausen of op Saterland, zoals ook Von Wicht volgens zijn marginale aantekening naderhand 
hausen ernaar gevraagd. ${ }^{121}$ Deze meldde dat hij weliswaar van zijn ouders gehoord had dat er enige lieden gewoond hadden die onder elkaar het 'Altfriesische' gesproken hadden, maar nu waren er geen meer. (In de marge tekent Matthias von Wicht jr. hier later bij aan dat het wellicht het 'Sagelterländische Dialekt' is geweest.) Te Westersander leven in elk geval wel mensen die 'das Altfriesische unterhalten'. Ook weet Von Wicht dat 'vor weniger Zeit' op Kloster Schoo in het ambt Esens nog mensen gewoond hebben die 'Altfriesisch' konden spreken. ${ }^{122}$

Deze constateringen zijn in verschillende opzichten interessant. Als eerste blijkt dat Von Wicht geen idee had dat in Friesland nog steeds Fries gesproken werd - en niet alleen in Molkwerum. Verder is de verbinding die hij legt tussen de 'oude taal', rechtsbronnen, vrijheid en identiteit kenmerkend voor meer geleerden en oudheidkundig geïnteresseerden van die tijd, zoals we hiervoor al konden waarnemen bij de zoektochten naar het Asegaboek.

Von Wichts gelijknamige zoon voegt aan deze constateringen nog toe dat er nog in 1778 in een kleine buurschap nabij Stade mensen waren die met hun buren Duits spraken, maar binnenshuis een vreemde taal die niemand kon verstaan. ${ }^{123}$ Ook kon men op Wangerooge nog 'Altfriesisch' spreken, wat men aldaar twiddern noemde. ${ }^{124}$

Uit de opmerkingen van vader en zoon Von Wicht kunnen we, denk ik, gevoeglijk concluderen dat in het westen van Oost-Friesland in de achttiende eeuw geen Friese enclaves als in Saterland, Harlingerland, Butjadingen, Wursten en op Wangerooge meer bestonden. Als deze daar nog wél bestaan hadden, dan had men toch mogen aannemen dat zij er weet van gehad hadden. Ik ga er daarom vanuit dat het niet overgeleverde Glossarium linguae vulgaris sive rustica Frisiae orientalis sive Samlung een Plattdüütsch of in elk geval Nederduits glossarium geweest is. Was het een historisch, Fries woordenboek geweest, dan had Von dem Appelle ongetwijfeld

concludeert. Zie voor het Fries in Molkwerum: H.T.J. Miedema, 'Kenmerken van het uitgestorven Molkwerums dialect en van het Hindeloopens', Taal en Tongval 38 (1986) 46-78.

121. Cornelius Behrends overleed in 1755 te Potshausen, 97 jaar oud. Als deze jaartallen en leeftijden kloppen, zou Von Wicht hem dus rond 1730 gesproken moeten hebben. E. Schulte, Die Familien der Kirchengemeinde Potshausen (1685-1900) (Aurich 1992) 82.

122. Dep. 1 Msc, inv.nr. Q 153, fol. 267r-271v.

123. Met verwijzing naar: J.A. De Luc, Lettres Physiques et morales sur l'histoire de la terre et de l'homme, dl.V (Den Haag/Parijs 1779) 284

124. Dep. 1 Msc, inv.nr. Q 153, fol. 267r. 
het woord 'Frisica' in de titel gebruikt. Overigens heb ik niet kunnen vaststellen op welk moment van zijn leven hij dit glossarium heeft samengesteld.

\section{Na het verschijnen van het Ostfriesische Land-Recht in 1746}

Na de verschijning van zijn Ostfriesische Land-Recht heeft Von Wicht zijn actieve speurtocht naar Oudfriese rechtshandschriften blijkbaar op een laag

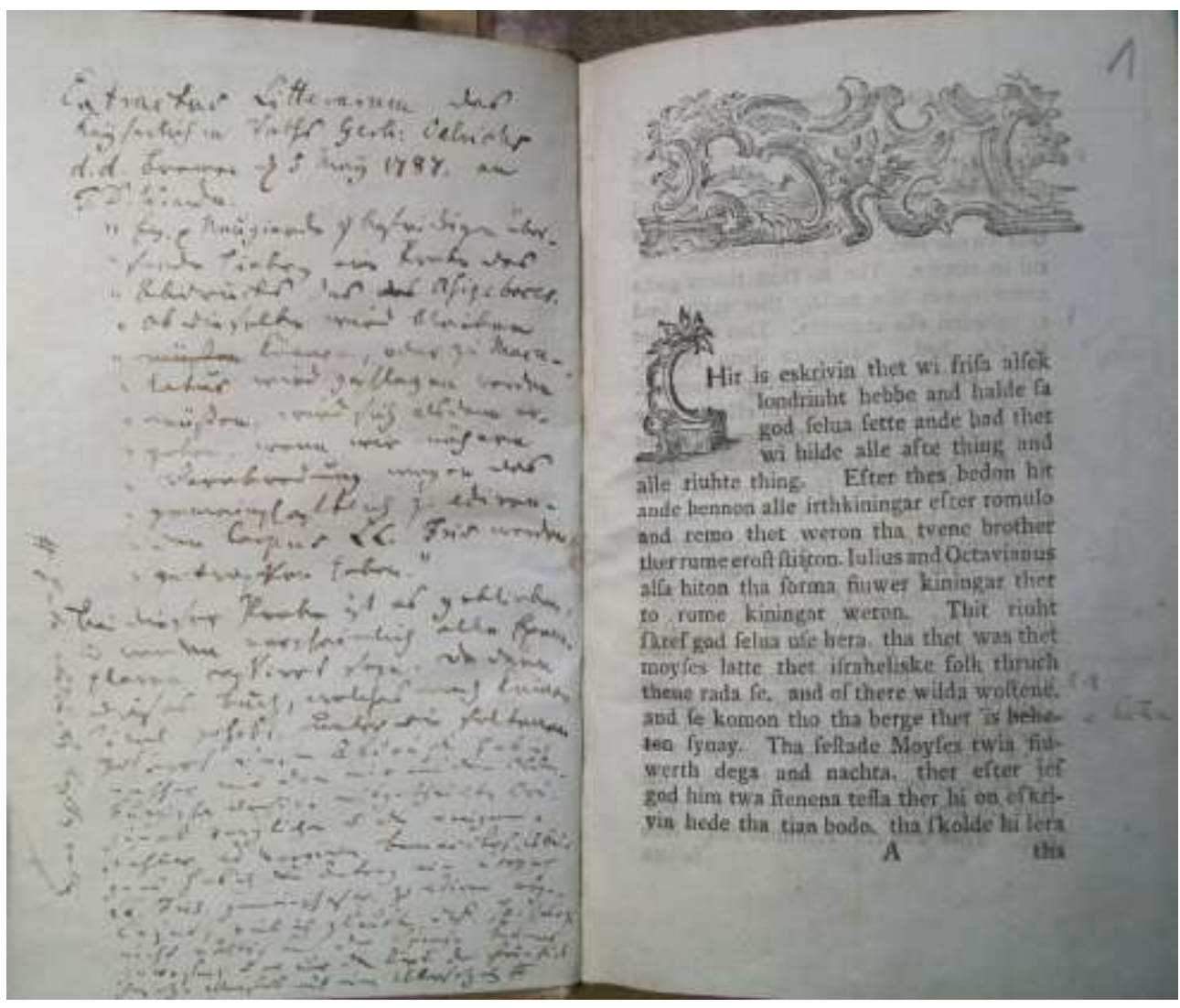

pitje gezet. ${ }^{125} \mathrm{Na}$ alle moeite om R1 in handen te krijgen, heeft hij zich niet meer gewaagd aan een poging om een tweede exemplaar boven water te krijgen. Schroetern schrijft in 1709 weliswaar expliciet dat hij vermoedt dat

125. Zie verder: A.T. Popkema, 'Die "Unvollendeten" von Matthias von Wicht (16941778) und Gerhard Oelrichs (1727-1789). Zu ihren unpubliziert gebliebenen altfrie- 
R1 zijns gelijke niet kent, ${ }^{126}$ maar Von Seelen meldt in 1725 dat hij uit de mond van Von Stade gehoord heeft dat die twee verschillende exemplaren heeft gebruikt. ${ }^{127}$ Dat suggereert dat deze laatste al vóór 1718 een tweede Oudfries Rüstringer handschrift gevonden had en de verleiding is groot daarin de Vorlage van R2 te zien. R2 is namelijk een afschrift uit de jaren tachtig van de achttiende eeuw van de hand van de Bremer syndicus Gerhard Oelrichs (1727-1789) naar een onbekend origineel. ${ }^{128}$ Oelrichs schrijft op 19 sept. 1772 aan Matthias von Wicht over zijn voornemen om 'das Aesgaboeck, wovon ich aus dem Oldenburgischen Archiv einen schönen Codicem erhalten habe, mit andern alten dahin gehörigen Rechtsbüchern abdrucken zu lassen'. ${ }^{129}$ Is dat de Vorlage van R2, die dan ook uit het archief te Oldenburg zou komen, of doelt hij daarmee gewoon op R1 zelf? Oelrichs heeft zijn plannen niet kunnen voltooien, al is wel een proefdruk bewaard gebleven van zijn uitgave van het Asegaboek, die hij op 5 mei 1787 aan Wiarda stuurde. ${ }^{130}$

Of Von Wicht na 1746 nog serieus werk heeft willen maken met zijn aangekondigde Historia juris Frisici is mij niet bekend. ${ }^{131}$ Wel heeft hij doorgewerkt aan zijn Vocabularium, waarbij hij gebruik gemaakt heeft van een verzameling van Von dem Appelle, de Farrago diplomatum ostfrisicarum, 'quam Dns. de Appelle collegit'. ${ }^{132}$ Op 22 oktober 1761 retourneert Von Wicht Von dem Appelles uiterst belangrijke verzameling afschriften van Oost-Friese oorkonden aan de schrijver en rechtmatige eigenaar, met excuses voor de langdurige bruikleen.

'Weit großere Ursache habe ich, wegen des so lange unter mir behaltenen Schatzes der Farraginis Diplom. Ostfris. bey E. HochWohlgeb. um Vergebung zu bitten. Ich remittire aber dieselbe nunmehro mit dem allerverpflichtesten Dank und erwiedere nochmahls meine Bitte, daß es E. HochWohlgeb. gefällig seyn möchte, dieses Werk, welches gewiß auch dermahleinst für Auswärtige von sehr nutzbaren Gebrauch seyn

sischen Rechtssammlungen sowie von Wichts neu-entdecktem "Vocabularium Frisicum Glossatum", in voorbereiding.

126. Memoria, 282.

127. Memini, olim ex ore Stadenii audivisse, quod duo huius libri, nunquam editi, usuraverit exemplaria, quorum alterum fuerit ab altero diversum. Memoria, 111.

128. W.J. Buma, Het Tweede Riustringer Handschrift ('s-Gravenhage 1954) 2.

129. Dep. 1 Msc, inv.nr. Q 153, fol. 315r.

130. Dep. 1 Msc, inv.nr. O 111.

131. Von Wicht, Ostfriesische Land-Recht, Vorbericht, 140.

132. Dep. 1 Msc, inv.nr. Q 153, fol. 162v, 167v, 175v, 250v, 275v, 276r, 289v. 
kan, an Stellen, welche diesen nicht verständlich, durch kurtze Anmerkungen zu erläutern, wozu allenfalls meine schuldige Dienste und Beyhülffe gerne offerire, wenn mir nur die etwahige dunckele und unverständliche Passus nur brevibus angezeiget würden., 133

Dit is tevens het enige bewijs van direct contact tussen de beide heren. Maar wanneer heeft Von Wicht de Farrago geleend? En hoe lang is 'so lange'? Von dem Appelle heeft het handschrift aangelegd in 1741, naar eigen zeggen om de ledigheid te verdrijven. Ongetwijfeld is dit het handschrift dat Von Wicht geleend heeft.

Enige jaren later heeft Von dem Appelle een tweede deel vervaardigd. Daarin zijn ook drie afschriften van oorkonden uit het vorstelijk archief te Aurich opgenomen, in 1737 en 1743 vervaardigd door Matthias von Wicht en door hem van noten voorzien. ${ }^{134}$ Of Von dem Appelle deze afschriften direct van Von Wicht ontvangen heeft en wanneer, durf ik niet te zeggen. Tegelijk met het eerste deel van de Farrago stuurt Von Wicht aan Von dem Appelle ook nog 'die verlangte alte Documenta, großentheils das Haus Dornum betreffend (14 an der Zahl), worunter einige sehr beträchtlich seyn'. Dit zullen in elk geval niet de afschriften zijn die Von dem Appelle in het tweede deel van zijn Farrago opgenomen heeft, want die handelen niet over Dornum.

In zijn brief van 22 oktober 1761 gaat Von Wicht ook nog in op H1. Zou het niet mogelijk zijn om dat handschrift 'noch endlich einmahl aufzutreiben'? En ook om het oude in Keulen gedrukte landrecht (Druk) in handen te krijgen? Dat laatste zou in Groningen 'vorhanden' en zelfs te koop zijn, zij het voor 50 gulden. 'Dies ist ein sehr hoher Preis!'. Wel is hij bereid het te ruilen tegen een exemplaar van Cornelis Agrippa, De occulta Philosophia. Hij kent echter in Groningen niemand via wie hij deze zaak zou kunnen regelen en verzoekt Von dem Appelle of die daarbij kan helpen.

Uit het feit dat Von Wicht de vragen over H1 en Druk nu blijkbaar voor het eerst aan Von dem Appelle stelt, terwijl dit twintig à dertig jaar eerder voor hem urgenter was, maak ik op dat zij in de decennia daarvóór weinig

133. Dep. 4 IX, inv.nr. 5a, los blad achterin het handschrift.

134. Fol. 65r: Ex Membrana Archivi Auricani Principis descripsit Matth. a Wicht, Ao. 1737, qui et subscriptam adjecit notam. Fol. 65v: Ex Membrana Archivi Principis Auric. descripsit Matthias a Wicht,1737, qui et sequentes ad[j]ecit notas. Fol. 66r: Ex originali Membrana, duobus sigillis, temporis injuriae detritis, munita, quae in Archivio Principali Auric. adservatur, fideliter atque verbotenus exscripsit, 11. Oct. 1743 M. a Wicht, qui et hocce instrumentum in Articulas divisit rubricas, notasque marginales adjecit. 
contact hebben gehad en enkel afschriften van oorkonden hebben uitgewisseld. Of de bejaarde Von dem Appelle zich nog heeft ingezet om aan Von Wichts verzoeken te voldoen, is de vraag. In hetzelfde jaar 1761 werd overigens in Groningen het rechtsgeleerd genootschap Pro excolendo iure patrio opgericht, waarvoor Von Wicht als corresponderend lid uitgenodigd werd. Zo werden dus ten slotte toch nog contacten tussen Von Wicht en Groningen gelegd.

Von dem Appelle heeft zich de laatste decennia van zijn leven nauwelijks met Oudfries bezig gehouden. Hij bleef zich op de hoogte houden van relevante literatuur, maar gebruikte die uitsluitend als historische of genealogische bron. ${ }^{135}$ De Oudfriese Emsiger Domen haalt hij enkel aan voor de daarin vermelde namen. ${ }^{136}$ Een enkele keer geeft hij woordverklaringen van Oudfriese woorden, waarbij hij op de verwantschap met Engels wijst. ${ }^{137}$

\section{Een mysterieuze brief}

Als laatste gaan we nog in op de hierboven al genoemde ongedateerde brief, in de hand van Von dem Appelle, gevoegd voorin zijn Linguae antiquae Frisiacae monumenta et glossarium. ${ }^{138}$ Het is opmerkelijk genoeg een Friestalige brief, met gedeeltelijke interlineaire Franse vertaling.

Mon trez grand Amy, et trez honorè parent.

Myn greate Stalcke, in heag geachte meegh

Votre chere lettre ay je bien recû quoique j' Jon oongenamme schrieuwinge hab ick wol ontfinzen, al hoe wol ick ay vû que vou ne scavier ou dans ce monde j'etois verstien hab, Jon E. naet wiste wor dat ick in wyde wrad wier

135. Zo blijkt uit een verwijzing naar Johan Henrich Pratje, 'Nachrichten von den Donationen welche die Königin Christina mit den Domanial- u. geistlichen Gütern in den Herzogthümern Bremen u. Verden vorgenommen, aus der Handschrift mitgetheilet', in: dez., Die Herzogthümer Bremen und Verden oder vermischte Abhandlungen V (Bremen 1761) 339, in Dep. 4 IX, inv.nr. 9a, fol. 142v.

136. Dep. 4 IX, inv.nr. 9a, fol. 142v, aangehaald naar Von Wicht, Ostfriesische LandRecht, 646, zoals blijkt uit de mislezing van 'alle' i.p.v. 'alla' (vgl. Fokkema, Derde Emsinger Codex, 38). Schijnbaar zonder specifieke bedoeling heeft hij verder nog de Oudfriese Tien Geboden uit H1 overgeschreven in een genealogisch handschrift (Dep. 4 IX, inv.nr. 7, fol. 152r).

137. Dep. 4 IX, inv.nr. 5a, fol. 25r, ad 'der Ztyucks feen': 'Ztyurks Feen h.e. pascuum ecclesiae Ztyurck Frisiis, Church Anglis, ecclesia.’Dep. 4 IX, inv.nr. 6, fol. 37r: 'nuer, i.est never ein altes Friesisches, noch im Englischen gebrauchliches Wordt, bezeignend niemahls.

138. Dep. 1 Msc, inv.nr. 60 


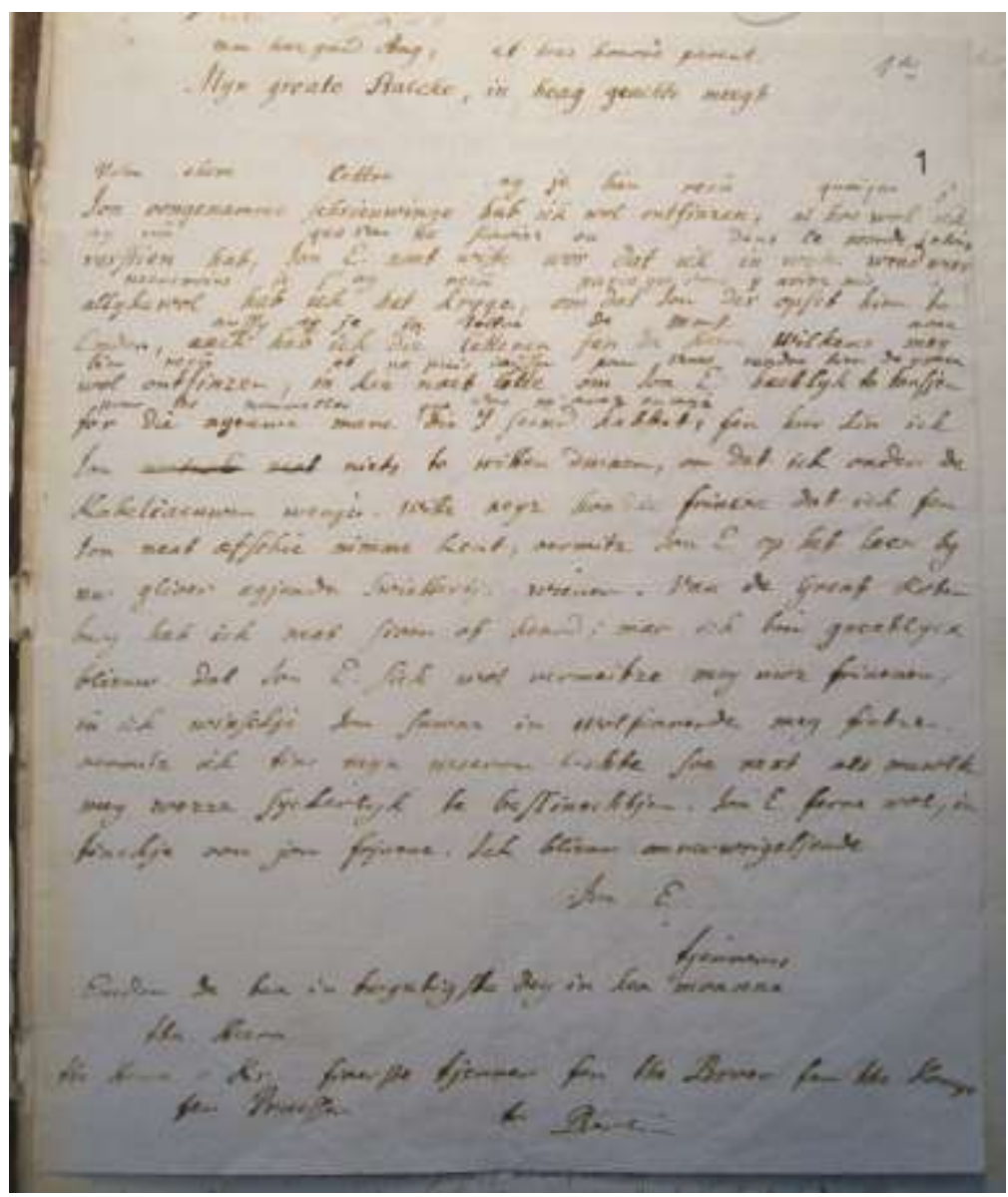

neansmoins je l'ay recû parce que vous y avier mis a allykewol hab ick het kryge, om dat Jon der opset hien to aussy ay je la lettre de mons. avec Emden, ææck hab ick die letteren fen de Heera Wilkens mey bien recû et ne puis laisser pour vous rendre bien de grace wol ontfinzen, in kin naet litte om Jon E. hæchlyk to tansjen pour les nouvelles que vou m'avez envoyè for die nyeuwe mare die y seind habbet, fen hier kin ick Jon niets E. neat niets to witten dwaen, om dat ick onder de Kabeliaeuwen wenje. Witte neyz hoalsche friuene dat ick fen Jon neat æfschie nimme kent, oermitz Jon E. op het laen by uw glioer ægjende Swiettertje wienen. Van de Greaf Rotenburg hab ick neat sioen of heard; mar ick bin greatlycx blieuw dat Jon E. sick wol vermeitze mey uwz friuenen 
in ick winsckje Jon suwne in wolfearende mey fintzen. oermitz ick tins myn weerom tochte soe next als muwlk mey werre syckerlyk te besliuechtjen. Jon E. ferre wol, in tinckje oon jon frjuene. Ick blieuw onverwrigeljende

Jon E.

tjenneres

Emden de tua in twyntigste dey in hea moanne

tha Heera

the Heera $v$ Kr. fioerste tjenner fen the Broer fen the Konige fen Pruessen

$$
\text { to Berlin }
$$

Voorzover ik weet, is dit het enige achttiende-eeuwse Friestalige geschrift uit Oost-Friesland. Onder de mij bekende geschriften van Von dem Appelle is mij geen ander spoor van actief gebruik van het Fries gebleken. Het is moeilijk voor te stellen dat de brief serieus bedoeld is. Hij wekt eerder de indruk dat de schrijver ervan wil laten zien hoe een Friestalige brief eruit ziet, waarbij hij die samengesteld heeft uit hem bekende woorden en uitdrukkingen. De bron werd mij aangedragen door Oebele Vries, die constateerde dat de brief deels bestaat uit woorden en passages die letterlijk zo voorkomen in de brieven van Gysbert Japicx aan Gabbema. Von dem Appelle bezat dit boek inderdaad, zoals blijkt uit zijn bibliotheekcatalogus. ${ }^{139}$

Hier volgen enkele voorbeelden van passages die aan de brieven van Gysbert Japicx zijn ontleend: 'Myn greate Stalcke' (Myn grea(t)te Stalcke; passim), 'Jon oongenamme schrieuwinge hab ick wol ontfinzen' (hab ick jon oongenamme schrieuwinge wol ontfinzen; 44), ${ }^{140}$ 'kin naet litte om Jon E. hæchlyk to tansjen for' (kin ick naet litte om Jon Ed. yn dy tealle haechlyk to teansjen; 57), 'fen Jon neat æfschie nimme' (aefschie fen jon E. to nimmen; 59), 'glioer ægjende Swiettertje' (gljoeraegjende swiettertjes; 47), 'ick winsckje Jon suwne in wolfearende' (winschje ' $k$ jo suwne in wolfearrende; 47), 'ferre wol, in tinckje oon jon frjuene' (ferre wol in tinckje oon jon frjuene; 46), 'Ick blieuw onverwrigeljende Jon Ed.' (Ick blieuw alle heel in onverwriggeljende jon Ed.; 59).

Ook de meeste woorden van de brief zijn bij Gysbert Japicx terug te vinden, al zijn er ook uitdrukkingen die aan de duim van de achttiende-

139. Dep. 4 IX, inv.nr. 63, pag. 173.

140. Bladzijdenummers naar Gysbert Japix, Friesche Rymlerye, dl.2 (Leeuwarden 1681). 
eeuwse schrijver zijn ontleend: 'die letteren' (brief), 'nyeuwe mare', 'soe next als muwlk', 'om dat ick onder de Kabeliaeuwen wenje'.

Uit dit alles moeten we opmaken dat de brief een pastiche was, geen bron voor actief gebruikt achttiende-eeuws Fries, maar geleerde Spielerei.

Deze brief kent geen afzender, geen jaar en enkel een cryptische omschrijving van de geadresseerde. De aanduiding van de laatste geeft echter wel enig houvast. Koning Frederik Willem I van Pruisen († 31 mei 1740) had geen broers. Hij werd opgevolgd door Frederik II de Grote, die drie jongere broers had: Augustus Willem (1722-1758), Frederik Hendrik (17261802) en Augustus Ferdinand (1730-1813). Dat geeft aan de brief een duidelijke terminus post quem. Onderzoek naar de hoffunctionarissen halverwege de achttiende eeuw leverde twee kandidaten op voor de aangeschreven 'v. Kr.'. Friedrich von Creutzen (1703-1765) was sinds 1736 Hofmarschall van de toen veertienjarige Augustus. In 1740, kort na de troonbestijging van Frederik II, werd hij aangesteld als gouverneur van diens jongere broers Hendrik en Ferdinand. In 1744 keerde hij als majoor terug naar het leger. Dat hij de aangeschrevene zou zijn lijkt minder waarschijnlijk. Hij is maar zeer kort 'eerste dienaar van de broer van de koning' geweest en hij stamt uit een familie uit de nabijheid van Koningsbergen in Oost-Pruisen. Dat maakt het opmerkelijk dat Von dem Appelle (die ik als afzender zie) hem een Friese brief zou sturen en hem 'meegh' noemt.

De tweede kandidaat is waarschijnlijker - en interessanter bovendien: Carl Friedrich von Kraut (1703-1767), die in 1746 Hofmarschall van prins Augustus werd en in 1750 van diens broer Hendrik. Dit bleef hij tot zijn overlijden. Zijn vader, Christian Friedrich (von) Kraut, was in 1686 op voorspraak van minister Dodo von Inn- und Knyphausen in Brandenburgse dienst gekomen, ${ }^{141}$ en bracht het tot Pruisisch geheime krijgsraad. Carl Friedrichs oom Johann Andreas Kraut was tezelfder tijd minister. Een verwantschap tussen Von dem Appelle en Kraut heb ik nog niet kunnen aanwijzen, noch een Friese afstamming.

Meer kansen voor een familierelatie met Von dem Appelle biedt Krauts echtgenote. Op 8 september 1756 huwt Carl Friedrich, dan al 53 jaar oud, met de 24-jarige Else Sophie von Platen (1731-1795). ${ }^{142}$ Von dem Appelle beschrijft de grafzerk van de grootvader van zijn schoonmoeder Juliana von Wersabe te Leer. Onder de zestien kwartieren vinden we ook het wapen

141. S. Isaacsohn, 'Krautt, Christian Friedrich von', Allgemeine Deutsche Biographie XVII (1883) 89-90; Von Alvensleben, Lütetsburger Chronik.

142. S. Freifrau von Thuemmler, Die Krautenmutter. Das Leben der Sophie von Platen (Norderstedt 2018). 
Von Platen. ${ }^{143}$ Die verwantschap lag ver terug in de tijd, op zijn laatst in de vijftiende eeuw, maar ongetwijfeld was deze verre relatie tussen hun beider echtgenotes voor de genealoog Von dem Appelle voldoende aanleiding om Kraut als 'meegh' aan te duiden. ${ }^{144}$

Voor de datering van de brief betekent dit dat die van na het huwelijk in 1756 tussen Kraut en Else Sophie von Platen moet stammen en van vóór 1767, het jaar dat zowel Von dem Appelle als Kraut overleden, Von dem Appelle op 5 mei, Kraut op 23 december. Niet uitgesloten moet overigens worden dat 'meegh' duidt op een standsgenoot, wat onder adellijke correspondenten niet ongebruikelijk is. In dat geval kan de brief ook vóór 1756 zijn opgesteld.

Dat de Berlijnse Hofmarschall Kraut banden met Oost-Friesland had, lijkt te worden bevestigd door het bewogen leven van zijn enige kind, Luise Charlotte Henriette von Kraut (1762-1819). Zij leeft vooral voort omdat zij als de 'Krautentochter' vereeuwigd werd door Theodor Fontane, geboren in haar sterfjaar. ${ }^{145}$ Luise huwde op zestienjarige leeftijd met de Engelse gezant aan het Pruisische hof, Hugh Elliot (1752-1830). Zij kreeg kennis aan de kamerheer Georg Anton Wilhelm von Inn- und Knyphausen (17441789). Nadat dit was uitgekomen, werd Georg door Elliot tot een duel uitgedaagd. Beiden overleefden dit. In 1783 werd de scheiding uitgesproken, waarna Luise en Georg in het geheim huwden. Zo werd Luise een barones Knyphausen, door het huwelijk met de achterkleinzoon van Dodo von Innund Knyphausen, de man die haar grootvaders carrière op gang had geholpen. In 1789 stierf de kamerheer en Luise hertrouwde ten derden male. In 1809 eindigde ook dit huwelijk in een scheiding. Tien jaar later stierf Luise, waarbij zij een met grote schulden beladen erfenis naliet.

We hebben de verleiding niet kunnen weerstaan om wat langer bij de dochter van Carl Friedrich von Kraut te blijven stilstaan vanwege de relatie met de Knyphausens en zo met Oost-Friesland. Dit maakt het immers des te waarschijnlijker dat hij de de gezochte 'v. Kr.' is.

Dat Von dem Appelle Kraut persoonlijk kende en een vriendschappelijke relatie met hem onderhield, is zeker niet uit te sluiten. Hij heeft immers Ber-

143. Dep. 4 IX, inv.nr. 9a, pag. 106, fol. 57v.

144. De genealogische aantekeningen die Von dem Appelle, vermoedelijk in de jaren dertig van de 18de eeuw, over de familie Von Platen maakte (Dep. 4 IX, inv.nr. 14, pag. 55 , fol. 32v) zijn zeer beperkt. Een exacte familierelatie tussen zijn echtgenote en Else Sophie von Platen zal hij niet bepaald kunnen hebben.

145. Theodor Fontane, Fünf Schlösser. Altes und Neues aus Mark Brandenburg (Stuttgart 1889) 81-146. 
lijn en Potsdam verschillende keren bezocht, o.a. in $1755 .{ }^{146}$ Het blijft wel merkwaardig dat Von dem Appelle aan deze Berlijnse hoffunctionaris van Maagdenburgse afkomst een brief in het Fries zou schrijven. Ik wil dan ook niet geheel uitsluiten dat we op zoek moeten naar nog een andere 'v. Kr.'. De andere in de brief genoemde personen, de Graf von Rothenburg en de heer Wilkens, heb ik niet eenduidig kunnen identificeren.

\section{Conclusie}

Tot dusver was volslagen onbekend dat de achttiende-eeuwse Oost-Fries Heinrich Bernhard von dem Appelle zich heeft beziggehouden met de bestudering van het (Oud)fries. De verklaring voor het feit dat zijn activiteiten op dit terrein steeds onopgemerkt zijn gebleven, zal zijn dat hij er nooit iets over heeft gepubliceerd. Dit onderscheidt hem van zijn generatieen landgenoot Matthias von Wicht, die door zijn omvangrijke publicatie van het Oost-Friese landrecht bekendheid heeft verworven als kenner van het Oudfries. Een ander verschil met Von Wicht is dat Von dem Appelles onderzoekingen in hoge mate bemoeilijkt werden door de politieke ontwikkelingen in Oost-Friesland. Doordat zij tot verschillende politieke kampen behoorden, was een actieve uitwisseling tussen deze beide OostFriezen lange tijd uitgesloten. Pas op gevorderde leeftijd hebben zij met zekerheid contact gehad. Bovendien is het toen mogelijk bij een enkel briefje gebleven.

Von dem Appelles grootste verdienste voor de frisistiek is wel dat hij de ontdekker is van het 'Ms. Wicht' (H1). Daarnaast mag hij een pionier op het terrein van de studie van het Oudfries in de vroege achttiende eeuw genoemd worden. In veel opzichten zijn zijn onderzoekingen typerend voor de wijze waarop in die tijd de frisistiek bedreven werd. Door zijn ballingschap bevond Von dem Appelle zich lange tijd in een betrekkelijk isolement, maar dat is niets uitzonderlijks. Ook de andere spelers op het veld waren gevangen, geografisch, door de beperkte beschikbaarheid van bronnen en door een door hun discipline beperkt blikveld. Pas na het eind van de achttiende eeuw konden deze hindernissen genomen worden en kon de frisistiek tot wasdom komen.

Warffum

mail@redmeralma.nl

146. JaL-B, Ms. Kunst, nr. 155 (oud 149a), 'Erinnerungen von Potsdam, 4 Januarii 1755 und Erinnerungen vom königl. Lust-Schloß Sans Soucy bey Potsdam, 4 Januarii $1755^{\prime}$, met gedetailleerde beschrijvingen. 